medRxiv preprint doi: https://doi.org/10.1101/2020.10.01.20204867; this version posted October 2, 2020. The copyright holder for this preprint (which was not certified by peer review) is the author/funder, who has granted medRxiv a license to display the preprint in perpetuity.

It is made available under a CC-BY-NC-ND 4.0 International license .

\title{
High-dimensional mass cytometry analysis of NK cell alterations in Acute Myeloid Leukemia identifies a subgroup with adverse clinical outcome
}

Anne-Sophie Chretien, Raynier Devillier, Samuel Granjeaud, Charlotte Cordier, Clemence Demerle, Nassim Salem, Julia Wlosik, Florence Orlanducci, Emilie Gregori, Magali Paul, Philippe Rochigneux, Thomas Pagliardini, Mathieu Morey, Cyril Fauriat, Nicolas Dulphy, Antoine Toubert, Herve Luche, Marie Malissen, Didier Blaise, Jacques A. Nunès, Norbert Vey, and Daniel Olive.

\section{Correspondence}

daniel.olive@inserm.fr

\section{Graphical abstract}

\section{NK cell maturation}

Early stages Late stages

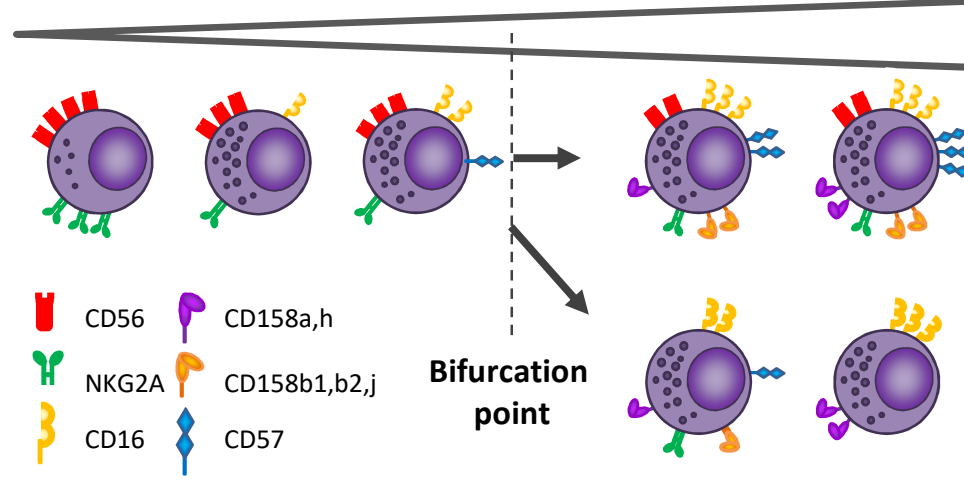

Healthy subjects

AML group 1

NK cells

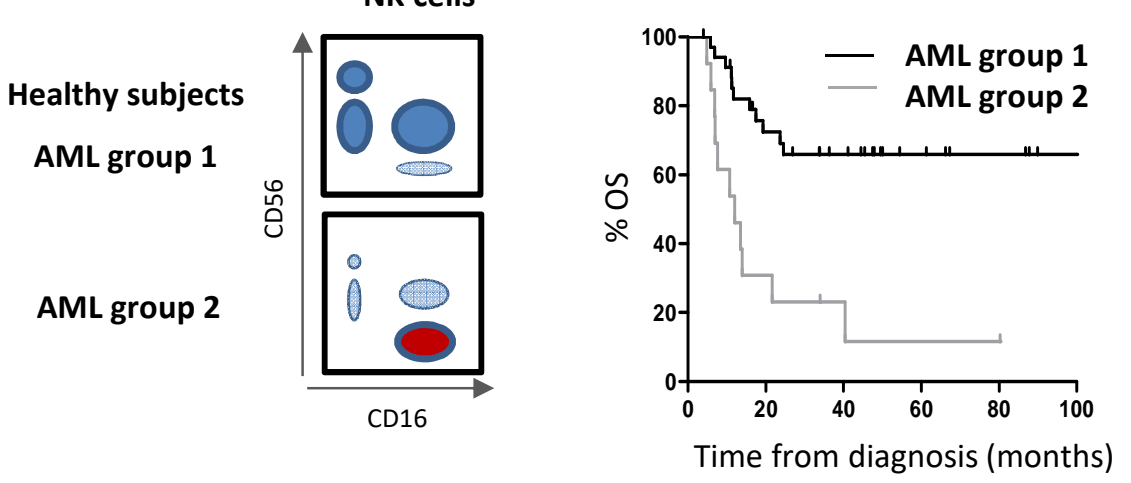

Key points:

- A disruption in the maturation process of NK cells leads to accumulation of unconventional CD56CD16 ${ }^{+} \mathrm{NK}$ cells in patients with $\mathrm{AML}$

- High frequency of $\mathrm{CD} 56^{-} \mathrm{CD} 16^{+} \mathrm{NK}$ cells is associated with adverse clinical outcome 


\section{High-dimensional mass cytometry analysis of NK cell alterations in Acute Myeloid Leukemia identifies a subgroup with adverse clinical outcome}

Anne-Sophie Chretien ${ }^{1,2}$, Raynier Devillier ${ }^{1-3}$, Samuel Granjeaud ${ }^{4}$, Charlotte Cordier ${ }^{1,2,5}$, Clemence Demerle ${ }^{1,2}$, Nassim Salem ${ }^{1,2}$, Julia Wlosik ${ }^{1,2}$, Florence Orlanducci ${ }^{1,2}$, Emilie Gregori ${ }^{6}$, Magali Paul ${ }^{7}$, Philippe Rochigneux ${ }^{1,2,8}$, Thomas Pagliardini $^{1-3}$, Mathieu Morey ${ }^{9}$, Cyril Fauriat ${ }^{1,2}$, Nicolas Dulphy ${ }^{10}$, Antoine Toubert ${ }^{10}$, Herve Luche ${ }^{6}$, Marie Malissen ${ }^{6,11}$, Didier Blaise ${ }^{1,3}$, Jacques A. Nunès ${ }^{1}$, Norbert Vey ${ }^{3}$, and Daniel Olive ${ }^{1,2}$.

\section{Author affiliations}

${ }^{1}$ Team Immunity and Cancer, Centre de Recherche en Cancérologie de Marseille (CRCM), Inserm, U1068, CNRS, UMR7258, Institut PaoliCalmettes, Aix-Marseille University, UM105, Marseille, France; ${ }^{2}$ Immunomonitoring department, Institut Paoli-Calmettes, Marseille, France; ${ }^{3}$ Hematology Department, Centre de Recherche en Cancérologie de Marseille (CRCM), Inserm, U1068, CNRS, UMR7258, Institut Paoli-Calmettes, Aix-Marseille University, UM 105, Marseille, France; ${ }^{4}$ Systems Biology Platform, Centre de Recherche en Cancérologie de Marseille (CRCM), Inserm, U1068, CNRS, UMR7258, Institut Paoli-Calmettes, Aix-Marseille University, UM 105, Marseille, France; ${ }^{5}$ Biopathology Department, Institut Paoli-Calmettes, Marseille, France; ${ }^{6}$ Centre d'Immunophénomique-Luminy (Ciphe), Inserm US012, CNRS UMS3367, Aix-Marseille University, Marseille, France; ${ }^{7}$ ImCheck therapeutics, Marseille, France; ${ }^{8}$ Medical Oncology Department, Institut Paoli-Calmettes, Marseille, France; ${ }^{9}$ Datactivist, Aix-en-Provence, France; ${ }^{10}$ Université Paris Diderot, Sorbonne Paris Cité, Institut Universitaire d'Hématologie, Immunology and Histocompatibility department, Hôpital Saint-Louis, APHP, Inserm UMRS-1160, Paris, France; ${ }^{11}$ Centre d'Immunologie de Marseille-Luminy (CIML), Inserm CNRS, Aix-Marseille University, Marseille, France.

\section{Corresponding author:}

Pr. Daniel Olive

Immunomonitoring Platform

Paoli-Calmettes Institute

Team Immunity and Cancer

Centre de Recherche en Cancérologie de Marseille (CRCM)

Inserm U1068

27 Boulevard Lei Roure CS 30059

13273 Marseille Cedex 09 - FRANCE

Phone: +33486977 271

daniel.olive@inserm.fr

Running title: $\mathrm{CD}^{-} 6^{-} \mathrm{CD} 16^{+} \mathrm{NK}$ cells in $\mathrm{AML}$

Key words: $\mathrm{AML}$, natural killer cells, $\mathrm{CD}^{-} 6^{-} \mathrm{CD} 16^{+} \mathrm{NK}$ cells, prognostic biomarkers, mass cytometry 
medRxiv preprint doi: https://doi.org/10.1101/2020.10.01.20204867; this version posted October 2, 2020. The copyright holder for this preprint (which was not certified by peer review) is the author/funder, who has granted medRxiv a license to display the preprint in It is made available under a CC-BY-NC-ND 4.0 International license

\section{ABSTRACT}

Natural killer (NK) cells are major anti-leukemic immune effectors. Leukemic blasts have a negative impact on NK cell function and promote the emergence of phenotypically and functionally impaired NK cells. In the present work, we highlight an accumulation of $\mathrm{CD} 56^{-} \mathrm{CD} 16^{+}$unconventional NK cells in acute myeloid leukemia (AML), an aberrant subset initially described as being elevated in patients chronically infected with HIV-1. Deep phenotyping of NK cells was performed using peripheral blood from patients with newly-diagnosed AML ( $N=48$, HEMATOBIO cohort, NCT02320656) and healthy subjects $(\mathrm{N}=18)$ by mass cytometry. We evidenced a moderate to drastic accumulation of $\mathrm{CD} 56^{-}$ CD $16^{+}$unconventional NK cells in $27 \%$ of patients. These NK cells displayed decreased expression of NKG2A as well as the triggering receptors NKp30, and NKp46, in line with previous observations in HIV-infected patients. High-dimensional characterization of these NK cells highlighted a decreased expression of three additional major triggering receptors required for NK cell activation, NKG2D, DNAM-1, and CD96. A high proportion of $\mathrm{CD}^{-} 6^{-} \mathrm{CD} 16^{+}$NK cells at diagnosis was associated with an adverse clinical outcome, with decreased overall survival $(H R=0.13 ; P=.0002)$ and event-free survival $(H R=0.33 ; P=.018)$, and retained statistical significance in multivariate analysis. Pseudo-time analysis of the NK cell compartment highlighted a disruption of the maturation process, with a bifurcation from conventional NK cells toward $\mathrm{CD}^{-} \mathrm{CD}^{-} 16^{+} \mathrm{NK}$ cells. Overall, our data suggest that the accumulation of $\mathrm{CD} 56^{-} \mathrm{CD} 16^{+} \mathrm{NK}$ cells may be the consequence of immune escape from innate immunity during $A M L$ progression.

\section{Significance}

This work provides the first report of accumulation of unconventional CD56-CD16+ NK cells in nonvirally induced malignancies. Pseudotime analysis highlights a bifurcation point occurring during the course of NK cell maturation, providing elements regarding the possible origin of CD56-CD16+ NK cells. Increased frequency of CD56-CD16+ NK cells is associated with adverse clinical outcome in AML and might contribute, as well as other maturation defects, to a defective control of AML progression. Overall, accumulation of CD56-CD16+ NK cells could be an important feature of immune escape from innate immunity. 
medRxiv preprint doi: https://doi.org/10.1101/2020.10.01.20204867; this version posted October 2, 2020. The copyright holder for this preprint (which was not certified by peer review) is the author/funder, who has granted medRxiv a license to display the preprint in It is made available under a CC-BY-NC-ND 4.0 International license .

\section{INTRODUCTION}

Natural killer (NK) cells are critical cytotoxic effectors involved in leukemic blast recognition, tumor cell clearance, and maintenance of long-term remission. ${ }^{1}$ NK cells directly kill target cells without prior sensitization, enabling lysis of cells stressed by viral infections or tumor transformation. NK cells are divided into different functional subsets according to CD56 and CD16 expression. ${ }^{2-4}$ CD56 bright $\mathrm{NK}$ cells are the most immature NK cells found in peripheral blood. This subset is less cytotoxic than mature NK cells and secretes high amounts of chemokines and cytokines such as IFNY and TNFa. These cytokines have a major effect on the infected or tumor target cells, and play a critical role in orchestration of the adaptive immune response through dendritic cell activation. CD56 ${ }^{\mathrm{dim}} \mathrm{CD} 16^{+} \mathrm{NK}$ cells, which account for the majority of circulating human NK cells, are the most cytotoxic NK cells. NK cell activation is finely tuned by integration of signals from inhibitory and triggering receptors, in particular NKp30, NKp46, and NKp44, DNAM-1, and NKG2D. ${ }^{5}$ Upon target recognition, CD56 ${ }^{\mathrm{dim}}$ CD16 ${ }^{+}$ NK cells release perforin and granzyme granules and mediate antibody-dependent cellular cytotoxicity through CD16 (FcyllIR) to clear transformed cells.

NK cells are a major component of the anti-leukemic immune response, and NK cell alterations have been associated with adverse clinical outcomes in acute myeloid leukemia (AML). ${ }^{6-9}$ Therefore, it is crucial to better characterize AML-induced NK cell alterations in order to optimize NK cell-targeted therapies. During AML progression, NK cell functions are deeply altered, with decreased expression of NK cell-triggering receptors and reduced cytotoxic functions, as well as impaired NK cell maturation. ${ }^{6,9-13}$ Cancer-induced NK cell impairment occurs through various mechanisms of immune escape, including shedding and release of ligands for NK cell-triggering receptors, release of immunosuppressive soluble factors such as TGF , adenosine, PGE2, or L-kynurenine, and interference with NK cell development, among others. ${ }^{14}$

Interestingly, these mechanisms of immune evasion are also seen to some extent in chronic viral infections, notably HIV. ${ }^{2}$ In patients with HIV, NK cell functional anergy is mediated by the release of inflammatory cytokines and TGF, the presence of $\mathrm{MHC}^{\mathrm{low}}$ target cells, and the shedding of ligands for NK cell-triggering receptors. ${ }^{2}$ As a consequence, some phenotypical alterations described in cancer patients are also induced by chronic HIV infections, with decreased expression of major triggering receptors such as NKp30, NKp46, and NKp44, ${ }^{15,16}$ decreased expression of CD16, ${ }^{17}$ and increased expression of inhibitory receptors such as $\mathrm{TIGIT}^{18}$ all observed. In addition, patients with HIV display an accumulation of $\mathrm{CD} 56^{-} \mathrm{CD} 16^{+}$unconventional NK cells, a highly dysfunctional NK cell subset. ${ }^{19,20}$ Mechanisms leading to the loss of CD56 are still poorly described, and the origin of this 
medRxiv preprint doi: https://doi.org/10.1101/2020.10.01.20204867; this version posted October 2, 2020. The copyright holder for this preprint (which was not certified by peer review) is the author/funder, who has granted medRxiv a license to display the preprint in It is made available under a CC-BY-NC-ND 4.0 International license .

subset of CD56 NK cells is still unknown. To date, two hypotheses have been considered: CD56 NK cells could be terminally differentiated cells arising from a mixed population of mature NK cells with altered characteristics, or could expand from a pool of immature precursor NK cells. ${ }^{21}$ Expansion of CD56 CD $16^{+}$NK cells is mainly observed in viral non-controllers. ${ }^{19,20}$ Indeed, CD56 is an important adhesion molecule involved in NK cell development, motility and pathogen recognition. ${ }^{22-27}$ CD56 is also required for the formation of the immunological synapse between NK cells and target cells, lytic functions, and cytokine production. ${ }^{26,28}$ As a consequence, $\mathrm{CD} 56 \mathrm{CD} 16^{+}$NK cells display lower degranulation capacities, decreased expression of triggering receptors, perforin, and granzyme $B$, dramatically reducing their cytotoxic potential, notably against tumor target cells. , $19,20,29,30$ In line with this loss of the cytotoxic functions against tumor cells, patients with concomitant Burkitt lymphoma and Epstein Barr virus infection display a dramatic increase of $\mathrm{CD} 56^{-} \mathrm{CD} 16^{+} \mathrm{NK}$ cells, ${ }^{30}$ which could represent an important hallmark of escape to NK cell immunosurveillance in virus-driven hemopathies.

To our knowledge, this population has not been characterized in the context of non-virally induced hematological malignancies. In the present work, we investigated the presence of this population of unconventional NK cells in patients with AML, its phenotypical characteristics, and the consequences of its accumulation on disease control. Finally, we explored NK cell developmental trajectories leading to the emergence of this phenotype.

\section{PATIENTS AND METHODS}

\section{Patients and study design}

This monocentric study (Paoli-Calmettes Institute, Marseille, France) included forty-eight patients with newly diagnosed non-acute promyelocytic leukemia AML from the HEMATOBIO cohort (NCT02320656). Patients were aged 19 to 80 years (mean $\pm S D=54.0 \pm 14.0$ ). All patients received cytarabine and anthracycline-based induction chemotherapy as previously described. ${ }^{43}$ Eight patients $(16.7 \%)$ were treated with allogeneic stem cell transplantation as a consolidation therapy. Patients' characteristics are summarized in Table 1.

\section{Ethics statement}

All participants gave written informed consent in accordance with the Declaration of Helsinki. The entire research procedure was approved by the institutional review board of the Paoli-Calmettes Institute. 
medRxiv preprint doi: https://doi.org/10.1101/2020.10.01.20204867; this version posted October 2, 2020. The copyright holder for this preprint (which was not certified by peer review) is the author/funder, who has granted medRxiv a license to display the preprint in It is made available under a CC-BY-NC-ND 4.0 International license .

\section{Clinical samples}

Peripheral blood mononuclear cells (PBMCs) cryopreserved in 90\% albumin/10\% DMSO were obtained before $(\mathrm{N}=48)$ and after induction chemotherapy ( $\mathrm{N}=16$, paired samples), and from agematched healthy volunteers $(\mathrm{N}=18)$. Handling, conditioning, and storage of samples were performed by the Paoli-Calmettes Tumor bank, which operates under authorization \# AC-2007-33 granted by the French Ministry of Research.

\section{Mass cytometry analysis}

PBMCs were thawed and processed as previously described. ${ }^{6}$ PBMCs were washed with RPMI 1640 medium with $10 \%$ fetal calf serum and incubated in RPMI 1640 with $2 \%$ fetal calf serum and $1 / 10000$ Pierce ${ }^{\circledR}$ Universal Nuclease $5 \mathrm{kU}$ (Thermo Fisher Scientific, Waltham, MA, USA) at $37^{\circ} \mathrm{C}$ with $5 \% \mathrm{CO}_{2}$ for $30 \mathrm{~min}$. Cells were centrifuged and incubated with cisplatin $0.1 \mathrm{M}$ to stain dead cells. Aspecific epitopes were blocked with $0.5 \mathrm{mg} / \mathrm{mL}$ Human Fc Block (BD Biosciences, San Jose, CA, USA). Two million PBMCs were stained for $45 \mathrm{~min}$ at $4^{\circ} \mathrm{C}$ with the extracellular antibodies (Supplemental Table 1). Cells were centrifuged and barcoded with the Cell-ID ${ }^{\mathrm{TM}}$ 20-Plex Pd Barcoding Kit (Fluidigm, San Francisco, CA, USA) according to the manufacturer's recommendations. Cells were washed and samples were combined and stained with metal-labeled anti-phycoerythrin secondary antibodies for $30 \mathrm{~min}$ at $4^{\circ} \mathrm{C}$. After centrifugation, cells were washed and permeabilized with the Foxp3 Staining Buffer Set (eBioscience, San Diego, CA, USA) for $40 \mathrm{~min}$ at $4^{\circ} \mathrm{C}$. Intracellular aspecific epitopes were blocked with $0.5 \mathrm{mg} / \mathrm{mL}$ Human Fc Block for $40 \mathrm{~min}$ at $4^{\circ} \mathrm{C}$ before incubation with the mix of intracellular antibodies for $40 \mathrm{~min}$ at $4^{\circ} \mathrm{C}$ in Foxp3 Staining Buffer (Supplemental Table 1). Cells were then washed and labeled overnight with $125 \mathrm{nM}$ iridium intercalator (Fluidigm) in Cytofix (BD Biosciences). Finally, cells were diluted in EQTM Four Element Calibration Beads (Fluidigm) before acquisition on a Helios ${ }^{\circledR}$ instrument (Fluidigm).

\section{Statistical analysis}

Statistical analyses were carried out using Graph Pad Prism V5.01 (San Diego, CA, USA) and SPSS V9.0 (Chicago, IL, USA). The $\chi^{2}$ or Fisher's exact test was used to assess association between variables. For multiple comparisons of paired values, a Friedman test was performed followed by a Dunn's posttest. Groups of patients with a high or low frequency of $\mathrm{CD} 56^{-} \mathrm{CD} 16^{+} \mathrm{NK}$ cells were defined based on optimized cut-points using maximally selected log-rank statistics (maxstat package, $\mathrm{R}$ software $\mathrm{V}$ 3.6.2 $)^{44}$ and on imposing that no group could represent fewer than $25 \%$ of patients. For survival analyses, overall survival (OS) was defined as the time from diagnosis until death from any cause, and event-free survival (EFS) as the time between induction and relapse, death from any cause, or induction failure, whatever occurred first. Patients without an event were censored the time of 
medRxiv preprint doi: https://doi.org/10.1101/2020.10.01.20204867; this version posted October 2, 2020. The copyright holder for this preprint (which was not certified by peer review) is the author/funder, who has granted medRxiv a license to display the preprint in It is made available under a CC-BY-NC-ND 4.0 International license .

their last follow-up. Survival times were estimated by the Kaplan-Meier method and compared using the log-rank test. A multivariate Cox regression model was used to assess the prognostic value of $\mathrm{CD}^{-} \mathrm{CD} 16^{+}$NK cells while adjusting for other prognostic factors. Candidate variables for the Cox regression were European Leukemia Net genetic classification, age at diagnosis, leukocytosis, and percentage of $\mathrm{CD} 56^{-} \mathrm{CD} 16^{+} \mathrm{NK}$ cells. Continuous variables were discretized as follows: age $<$ or $\geq 50$ years old; leukocytosis: $<$ or $\geq 50 \mathrm{G} / \mathrm{L} ; \mathrm{CD}^{-} 6^{-} \mathrm{CD} 16^{+}$NK cells: $<$or $\geq 10 \%$. All factors with a $P$ value $<.15$ in univariate analysis were considered to be candidates for the backward stepwise Cox regression model. For subgroup analyses, patients were divided into two groups, a relapsed AML group and a long-term complete remission group, according to clinical outcome after 24 months of follow-up. The limit of significance was set at $\mathrm{P}<.05$.

\section{Algorithm-based high-dimensional analysis}

NK cells were manually defined as $\mathrm{CD} 13^{-} \mathrm{CD} 33^{-} \mathrm{CD} 34^{-} \mathrm{CD} 45^{+} \mathrm{CD} 3^{-} \mathrm{CD} 19^{-} \mathrm{CD} 56^{+}$or $\mathrm{CD} 13^{-} \mathrm{CD} 33^{-} \mathrm{CD} 34^{-} \mathrm{CD} 45^{+}$ $\mathrm{CD}^{-} \mathrm{CD} 19^{-} \mathrm{CD} 56^{-} \mathrm{CD} 16^{+}$and exported using FlowJo V10.6.2. The gating strategy is displayed in Supplemental Figure 1. Data were arcsinh-transformed with a cofactor of 5 . NK cell populations were automatically defined using hierarchical stochastic neighbor embedding (h-SNE) analysis (Cytosplore V2.2.1) with default settings ( 30 perplexity and 1,000 iterations)..$^{45}$ For the $h$-SNE analyses, consensus files were generated for each group of patients with a fixed number of NK cells in order to obtain a representative and balanced view of all patient groups. NK cell trajectory inferences were performed using the Wishbone algorithm. ${ }^{32}$ The library was updated for Python V3.6 and is available at https://github.com/moreymat/wishbone/releases/tag/0.4.2-py.3.

\section{RESULTS}

\section{Accumulation of $\mathrm{CD} 566^{-} \mathrm{CD} 16^{+} \mathrm{NK}$ cells in patients with $\mathrm{AML}$}

PBMCs from 48 newly diagnosed AML patients were analyzed by mass cytometry. Based on expression of CD56 and CD16, we defined four NK cell subsets: CD56 ${ }^{\text {bright }}$ NK cells, CD56 ${ }^{\text {dim }}$ CD16 NK cells, CD56 ${ }^{\mathrm{dim}} \mathrm{CD} 16^{+}$NK cells, and $\mathrm{CD} 56^{-} \mathrm{CD} 16^{+}$NK cells (Supplemental Figure 1). In 5 out of 48 patients (10.4\%), we observed a massive accumulation of $\operatorname{CD} 56{ }^{-}$CD $16^{+}$NK cells, with more than $20 \%$ of total NK cells represented in this cluster. In 8 out of 48 patients (16.7\%), we observed a moderate accumulation of $\mathrm{CD}^{-} \mathrm{CD}^{-} 6^{+} \mathrm{NK}$ cells, with $10-19 \%$ of total NK cells represented in this cluster (Figure $1 \mathrm{~A}$ ). The threshold of $10 \%$ was defined on the basis of the maxstat algorithm (Supplemental Figure 2). Patients with $\leq 10 \% \mathrm{CD} 56^{-} \mathrm{CD} 16^{+} \mathrm{NK}$ cells are referred to as group $1(\mathrm{~N}=35)$ and patients with $>10 \% \mathrm{CD}^{-} \mathrm{CD} 16^{+} \mathrm{NK}$ cells are referred to as group $2(\mathrm{~N}=13)$ in the rest of the article (Figure $\left.1 \mathrm{~A}\right)$. 
medRxiv preprint doi: https://doi.org/10.1101/2020.10.01.20204867; this version posted October 2, 2020. The copyright holder for this preprint (which was not certified by peer review) is the author/funder, who has granted medRxiv a license to display the preprint in It is made available under a CC-BY-NC-ND 4.0 International license .

The frequency of $\mathrm{CD} 56^{-} \mathrm{CD} 16^{+} \mathrm{NK}$ cells was significantly higher in group 2 than in group 1 or in healthy volunteers, with mean frequencies of $24.9 \%$ vs $3.5 \%$ and $7.7 \%, \mathrm{P}<.001$ and $\mathrm{P}<.05$, respectively (Figure 1B). This threshold is illustrated on the intensity distribution graph using a kernel density estimation (Figure 1C).

More than 95\% of cells expressed the transcription factors T-bet and Eomes across the four NK cell subsets (Supplemental Figure 3A). However, as group 1 innate lymphoid cells (ILC1) share expression of T-bet with NK cells, ${ }^{31}$ we assessed expression of the ILC markers CD25, CD127 (IL7R), and CD278 (ICOS) to exclude the hypothesis that ILC1s were accumulated in patients in group 2. As expected, CD25 and IL7R expression was mostly restricted to CD56 bright NK cells, whereas expression was reduced in CD56 ${ }^{\mathrm{dim}}$ and $\mathrm{CD} 56^{-} \mathrm{NK}$ cells compared with other clusters of conventional CD56 ${ }^{+} \mathrm{NK}$ cells (Supplemental Figure 2B). In addition, more than 95\% of NK cells were ICOS, including those within the $\mathrm{CD} 6^{-} \mathrm{CD} 16^{+}$subset, further confirming that $\mathrm{CD}^{-} 6^{-} \mathrm{CD} 16^{+}$cells were not ILC1s (Supplemental Figure 3B).

\section{High-dimensional analysis of $\mathrm{CD}^{-} \mathrm{CD}^{-} 16^{+} \mathrm{NK}$ cells phenotypical characteristics}

Loss of CD56 expression on NK cells has been associated with a loss of two of the main NK celltriggering receptors, NKp30, NKp46, as well as NKG2A in HIV-infected patients. ${ }^{20}$ We used the h-SNE algorithm to explore NK cell alterations associated with accumulation of CD56 CD16 ${ }^{+}$NK cells in AML. As described in HIV infection, $\mathrm{CD}^{-} \mathrm{CD}^{-} 6^{+} \mathrm{NK}$ cells from patients with AML also exhibited a loss of NKp30, NKp46, and NKG2A (Figure 2A and B). In addition, h-SNE analyses revealed a loss of three additional major triggering receptors required for NK cell activation: NKG2D, DNAM-1, and CD96 (Figure 2A and B). Manual gating confirmed that a significantly lower percentage of $\mathrm{CD}^{-} 6^{-} \mathrm{CD} 16^{+} \mathrm{NK}$ cells than $\mathrm{CD} 56^{\mathrm{dim}} \mathrm{CD} 16^{+}$NK cells expressed the triggering receptors NKp30, NKp46, NKG2D, DNAM-1, and CD96 compared with $\mathrm{CD} 56^{\mathrm{dim}} \mathrm{CD} 16^{+} \mathrm{NK}$ cells in patients with $\mathrm{AML}$ (NKp30: 14.0 vs 47.4\%, P<.001; NKp46: 20.5 vs 58.9\%, $\mathrm{P}<.05$; NKG2D: 36.1 vs 84.7\%, $\mathrm{P}<.001$; DNAM-1: 35.7 vs 71.8\%, $\mathrm{P}<.001$; CD96: 21.2 vs $42.7 \%, \mathrm{P}<.05$ ) (Figure $2 \mathrm{C}$ ). No significant variation was observed regarding NKG2C expression (data not shown). Maturation profiles revealed that $\mathrm{CD}^{\circ} \mathrm{CD}^{\circ} 6^{+} \mathrm{NK}$ cells displayed significantly lower expression of maturation markers such as CD57 and Killer cell immunoglobulin-like receptors (KIRs) than conventional $\mathrm{CD} 56^{\mathrm{dim}} \mathrm{CD} 16^{+}$NK cells; CD57: 27.7 vs 61.8\%, $\mathrm{P}<.001 ; \mathrm{CD} 158 \mathrm{a}, \mathrm{h}: 9.8$ vs 19.8\%,

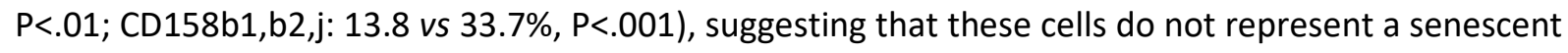
subset issued from terminally differentiated NK cells (Figure 3). However, these cells did not belong to an immature subset of NK cells either, since this population poorly expressed NKG2A compared with immature CD56 ${ }^{\text {bright }}$ NK cells $(17.9$ vs $77.1 \%, \mathrm{P}<.001)$ or with $\mathrm{CD} 56^{\mathrm{dim}} \mathrm{CD} 16^{+}$NK cells $(17.9$ vs $47.5 \%, P<.05$ ) (Figure 3). Most of the variations between $\mathrm{CD} 56^{\mathrm{dim}} \mathrm{CD} 16^{+} \mathrm{NK}$ cells and $\mathrm{CD} 56^{-} \mathrm{CD} 16^{+} \mathrm{NK}$ 
medRxiv preprint doi: https://doi.org/10.1101/2020.10.01.20204867; this version posted October 2, 2020. The copyright holder for this preprint (which was not certified by peer review) is the author/funder, who has granted medRxiv a license to display the preprint in It is made available under a CC-BY-NC-ND 4.0 International license .

cells were also present in healthy volunteers (Figure $2 \mathrm{C}$ and 3 ). Furthermore, $\mathrm{CD} 56^{-} \mathrm{CD} 16^{+} \mathrm{NK}$ cells displayed reduced expression of the anti-apoptotic proteins BCL-2 and BCL-XL compared with $\mathrm{CD} 56^{\mathrm{dim}} \mathrm{CD} 16^{+} \mathrm{NK}$ cells in both healthy volunteers and patients with AML (Figure 4).

\section{Evolution at complete remission}

When material was available, we then assessed variations of the frequency of CD56 CD $16^{+} \mathrm{NK}$ cells at complete remission compared with baseline frequencies (Supplemental Figure 4). A normal frequency of $\mathrm{CD}^{-} \mathrm{CD} 16^{+} \mathrm{NK}$ cells was not systematically restored after induction chemotherapy. After induction chemotherapy, 7 out of 16 patients (43.8\%) displayed less than $10 \%$ of $\mathrm{CD}^{-} 6^{-} \mathrm{CD} 16^{+}$ NK cells. Among them, 5 patients maintained long-term complete remission and 2 patients relapsed. Nine out of 16 patients (56.2\%) displayed more than $10 \%$ of $C D 56^{-} \mathrm{CD} 16^{+}$NK cells after induction chemotherapy. Among them, 3 patients maintained long-term complete remission and 6 patients relapsed.

\section{High frequency of $\mathrm{CD} 56^{-} \mathrm{CD} 16^{+} \mathrm{NK}$ cells at diagnosis is associated with adverse clinical outcome} Patients were classified into two groups according to the frequency of $\mathrm{CD} 56^{-} \mathrm{CD} 16^{+} \mathrm{NK}$ cells, using the thresholds of $10 \%$ defined above. The frequency of CD56 CD16 NK cells at diagnosis in patients with AML was analyzed according to clinical outcome after 24 months of follow-up. After induction therapy, complete remission rates were $82.9 \%$ and $69.2 \%$ in groups 1 and 2, respectively. Among patients without accumulation of $\mathrm{CD}^{2} 6^{-} \mathrm{CD} 16^{+} \mathrm{NK}$ cells (group 1), 18 out of 35 (54.3\%) patients were in continuous $\mathrm{CR}$ after 24 months of follow-up, whereas among patients with accumulation of CD56 CD16 ${ }^{+}$NK cells (group 2), 2 out of 13 patients were in continuous CR (15.4\%) (Figure 5A). Overall survival (OS) (hazard ratio $(H R)=0.13, P<.001)$ and event-free survival $(E F S)(H R=0.33, P<.05)$ were significantly reduced in patients with high frequency of $\mathrm{CD}^{-} 6^{-} \mathrm{CD} 16^{+} \mathrm{NK}$ cells as compared with patients that displayed a conventional NK cell profile, with 3-year OS and EFS rates of $23.7 \%$ vs $65.9 \%$ and $15.4 \%$ vs $50.4 \%$, respectively (Figure 5B). In multivariate Cox regression models, the frequency of $\mathrm{CD}^{\circ} \mathrm{CD}^{-} 16^{+} \mathrm{NK}$ cells retained statistical significance in both $\mathrm{OS}$ and $\mathrm{EFS}(\mathrm{HR}=0.19, \mathrm{P}=.0004 ; \mathrm{HR}=0.42$, $\mathrm{P}=.033$, respectively) (Table 2 ).

\section{Pseudo-time analysis}

The important question of the origin of these CD56 NK cells remained. Interestingly, in patients with AML, accumulation of $\mathrm{CD}^{-} \mathrm{CD}^{-} 6^{+}$NK cells was associated with a decreased frequency of conventional $\left(\mathrm{CD}^{-} \mathrm{CD} 56^{+}\right) \mathrm{NK}$ cells, thus suggesting that these NK cells are derived from the pool of conventional NK cells rather than expanded from the pool of immature precursor NK cells (Supplemental Figure 5). To probe this hypothesis, we performed a trajectory inference of NK cell 
medRxiv preprint doi: https://doi.org/10.1101/2020.10.01.20204867; this version posted October 2, 2020. The copyright holder for this preprint (which was not certified by peer review) is the author/funder, who has granted medRxiv a license to display the preprint in It is made available under a CC-BY-NC-ND 4.0 International license

maturation using the Wishbone algorithm. Wishbone is a recent algorithm used for analysis of developmental pathways in high-dimensional single-cell datasets. This algorithm positions single cells along bifurcating developmental trajectories on a k-nearest neighbor graph and pinpoints bifurcation points. ${ }^{32}$ The rise and fall of markers acquired or lost during the course of NK cell development (y axis) is represented as a function of pseudo-time (x axis) (Figure $6 \mathrm{~A}$ and $\mathrm{B}$ ). Each branch after the bifurcation point represents a distinct differentiation trajectory. Wishbone recovers hallmarks of NK cell maturation in healthy volunteers. NK cells initially highly express CD56 and NKG2A. CD56 bright NK cells expressing low levels of CD16 correspond to a transition between early immature CD56 ${ }^{\text {bright }} \mathrm{CD} 16^{-}$NK cells and $\mathrm{CD} 56^{\text {dim }} \mathrm{CD} 16^{+}$NK cells. Subsequently, NK cells lose expression of NKG2A and sequentially acquire KIRs (CD158a, $\mathrm{h}$ and $\mathrm{CD} 158 \mathrm{~b} 1, \mathrm{~b} 2, \mathrm{j})$ and finally $\mathrm{CD} 57$, which marks the acquisition of high cytotoxic potential ${ }^{4}$ (Figure $6 \mathrm{~A}$ ). In AML, the maturation process is disrupted and leads to a bifurcation point: the first branch displays a normal-like maturation profile, whereas the second branch displays altered maturation features, with decreased CD57 and CD158b1,b2,j expression, as well as loss and re-acquisition of CD16 (Figure 6B). These observations further support the hypothesis of a bifurcation from conventional NK cells toward $\mathrm{CD}^{-} \mathrm{CD}^{-} 16^{+} \mathrm{NK}$ cells during the maturation process.

\section{DISCUSSION}

Recent clinical trials highlight the central role of NK cells for the control of AML. ${ }^{33}$ Since NK cell alterations are expected to impact response to NK cell-based immunotherapies, a better characterization of evasion from NK cell surveillance is therefore an absolute prerequisite to design the next-generation of therapeutic strategies based on NK cell manipulation. In the present article, we highlight the presence of unconventional CD56 NK cells in $10 \%$ of patients with $\mathrm{AML}$, which is associated with adverse clinical outcomes. This variable appears to be an independent prognostic factor since it retains statistical significance in multivariate analysis. However, allogeneic stem cell transplantation was not equally distributed within groups 1 and 2, with 7 out of 35 patients (20\%) vs 1 out of 13 (7.7\%) receiving allo-SCT, respectively. This difference was not significant and could be partially explained by the lower complete remission rates in group 2 .

CD56 NK cells represent a minor subset of NK cells under physiological conditions. Their relative proportion increases in chronically infected HIV viremic patients, in which the CD56 CD $16^{+}$subset can represent up to $50 \%$ of total NK cells..$^{19,20,34,35}$ More recently, this population has been described in subjects co-infected with cytomegalovirus (CMV) and Epstein-Barr virus (EBV), with a moderate 
medRxiv preprint doi: https://doi.org/10.1101/2020.10.01.20204867; this version posted October 2, 2020. The copyright holder for this preprint (which was not certified by peer review) is the author/funder, who has granted medRxiv a license to display the preprint in It is made available under a CC-BY-NC-ND 4.0 International license .

increase in frequency. ${ }^{36}$ Elevated frequencies of $\operatorname{CD}^{-} 6^{-}$NK cells have also been described to a lesser extent in other viral chronic infections, such as hepatitis $C$ or hantavirus infections, ${ }^{37,38}$ and autoimmune ocular myasthenia. ${ }^{39}$ In these pathological situations, functional characterization of these CD56 ${ }^{-}$NK cells revealed profound dysfunctions. In HIV-infected subjects, CD56 CD16 ${ }^{+}$NK cells are reported to be highly dysfunctional, with reduced natural cytotoxicity, defective antibody-dependent cellular cytotoxicity, as well as low IFNy production capacity, although they retain chemokine secretion capacities. ${ }^{20,21}$ Phenotypical characterization of $\mathrm{CD}^{-} \mathrm{CD}^{-} 16^{+}$NK cells highlighted a decreased expression of the NK cell-triggering receptors NKp30 and NKp46, as well as a decreased expression of NKG2A. ${ }^{20}$ Whether this population of NK cells is induced by chronic exposure to antigens is unclear, and mechanisms involved in $\mathrm{CD}^{-} \mathrm{CD}^{-} \mathrm{6}^{+} \mathrm{NK}$ cell accumulation remain to be elucidated. Overall, previous reports suggest that these NK cells represent a subset of exhausted NK cells. ${ }^{20,21,35}$ Interestingly, an important downregulation of CD56 could be obtained in vitro using sera from patients with chronic lymphoid leukemia added to NK cells from healthy subjects, suggesting that this phenotype emerges in the presence of an immunosuppressive milieu. ${ }^{40}$

Beside the question of the mechanisms involved in the emergence of $\operatorname{CD} 56^{-} \mathrm{CD} 16^{+} \mathrm{NK}$ cells, the important question of the origin of this subset remained to be explored. We used a pseudo-time algorithm to explore differentiation trajectories that give rise to $\mathrm{CD}_{56} \mathrm{CD}^{-16^{+}} \mathrm{NK}$ cells. These algorithms were developed to investigate the fundamental questions of development processes from individual cells into different cell types. Interestingly, we could reconstitute the theoretical scheme of NK cell maturation in healthy subjects. Identification of a bifurcation occurring during the course of NK cell maturation in patients with AML provides answers regarding the possible origin of CD56 CD16 ${ }^{+}$NK cells, suggesting that accumulation of $\mathrm{CD}^{-} 6^{-}$NK cells would be the consequence of disruption of the maturation process. This observation provides bases for further exploration of the mechanisms involved in the emergence of this population, which will enable to better define therapeutic strategies likely to restore physiological frequencies of $\mathrm{CD}^{-} 6^{-} \mathrm{NK}$ cells. These elements must be considered with regards to other maturation anomalies our group described in AML, with a maturation blockade that affects approximately $10 \%$ of patients, for whom the clinical outcome is dramatic. ${ }^{6}$ As with maturation blockade, bifurcation toward CD56 NK cells has major consequences on clinical outcome. Hence, a normal NK cell maturation appears to be critical to control the disease and these anomalies urgently need to be further explored in AML. Interestingly, it has been reported that this phenotype is reversed when the viral load of patients with HIV was lowered below detectable levels after 12 months of antiretroviral therapy, a situation associated with considerable improvement in NK cell function, increased NK cell receptor expression, and restoration of normal CD56 expression. ${ }^{21}$ In the context of AML, the normalization of the frequency of CD56 NK cells was 
medRxiv preprint doi: https://doi.org/10.1101/2020.10.01.20204867; this version posted October 2, 2020. The copyright holder for this preprint (which was not certified by peer review) is the author/funder, who has granted medRxiv a license to display the preprint in It is made available under a CC-BY-NC-ND 4.0 International license .

observed only in some patients at the time of complete remission. This persistence of CD56 NK cells 30 days after induction chemotherapy should be explored at later time points to confirm these results.

To our knowledge, accumulation of CD56 NK cells has not been reported in hematological or solid malignancies, except in chronic natural killer cell large granular lymphocytosis (LGL), where there is a massive clonal expansion of CD56 ${ }^{\mathrm{dim} /-}$ NK cells in a subset of patients. ${ }^{41}$ According to the authors, CD56 NK cell expansion in LGL leukemia might be the consequence of an activating stimulus such as a retroviral infection, notably because sera from patients with LGL leukemia frequently react with HTLV-I/II p21 envelope proteins. Whether CMV infection could induce this aberrant phenotype has not been determined in our cohort, as we do not have CMV status data for all our patients. However, the increase in CD56 NK cells described in CMV and EBV co-infected subjects is moderate ${ }^{36}$ and therefore does not explain the massive accumulation we observe in $A M L$, although a synergistic mechanism cannot be excluded. Finally, we observed a higher prevalence of CD56 NK cell accumulation in AML with inversion 3 (inv 3); in 3 out of 4 patients, $\mathrm{CD}^{-} \mathrm{CD}^{-} 6^{+} \mathrm{NK}$ cells represented more than $20 \%$ of the total NK cell population. This association might represent an interesting feature of immune alteration in the group of patients with inv 3 for whom clinical outcome is extremely unfavorable, and requires confirmation in a larger cohort of patients. ${ }^{42}$

In conclusion, loss of CD56 expression by the NK cells of patients with AML might represent a feature of immune evasion from NK cell control. If the impact of such a phenotype on clinical outcome is confirmed, the frequency of CD56 NK cells at diagnosis might be informative in NK cell-based immune signatures to predict clinical outcome in AML. Lastly, exploration of the mechanisms involved in downregulation of CD56 will provide new opportunities to restore NK cell functions in this specific subgroup of patients. 
medRxiv preprint doi: https://doi.org/10.1101/2020.10.01.20204867; this version posted October 2, 2020. The copyright holder for this

preprint (which was not certified by peer review) is the author/funder, who has granted medRxiv a license to display the preprint in It is made available under a CC-BY-NC-ND 4.0 International license .

\section{ACKNOWLEDGMENTS}

The authors thank the CRCM cytometry core facility as well as the IPC/CRCM/UMR 1068 Tumor Bank, which operates under authorization \# AC-2007-33 granted by the French Ministry of Research (Ministère de la Recherche et de l'Enseignement Supérieur). Louise Ball from Angloscribe, an independent scientific language editing service, provided drafts and editorial assistance to the authors during preparation of this manuscript. This work has been financially supported by the INCa (grant 2012-064/2019-038 for D.O., and A.T.), the Fondation de France (grant 00076207 for A.S.C), the SIRIC Marseille (grant INCa-DGOS-INSERM 6038), the Cancéropôle PACA (grants K_CyTOF 2014 and AML_CyTOF 2016 for J.A.N.), the GS IBiSA and the Agence Nationale de la Recherche (PHENOMIN project for M.M., H.L., and E.G.). The team "Immunity and Cancer" was labeled "Equipe FRM DEQ 201 40329534" (for D.O.).

\section{AUTHORSHIP}

\section{Contribution:}

C.C., C.D., E.G., F.O., M.P., and N.S. performed experiments

A.-S.C., H.L., J.W., M.M., P.R., and S.G., analyzed results and prepared the figures

A.-S.C., A.T., C.F., D.B., D.O., H.L., J.A.N., M.M., N.V., R.D., and T.P. designed the research and wrote the article

\section{Conflict-of-interest disclosure:}

The authors declare no relevant conflicts of interest

Correspondence: Daniel Olive, Immunomonitoring Platform, Paoli-Calmettes Institute, Team Immunity and Cancer, Centre de Recherche en Cancérologie de Marseille (CRCM), Inserm U1068, 27 Boulevard Lei Roure CS 30059, 13273 Marseille Cedex 09, France; daniel.olive@inserm.fr 
medRxiv preprint doi: https://doi.org/10.1101/2020.10.01.20204867; this version posted October 2, 2020. The copyright holder for this preprint (which was not certified by peer review) is the author/funder, who has granted medRxiv a license to display the preprint in

It is made available under a CC-BY-NC-ND 4.0 International license .

\section{REFERENCES}

1. Morvan MG, Lanier LL. NK cells and cancer: you can teach innate cells new tricks. Nat Rev Cancer. 2016;16(1):7-19.

2. Lucar O, Reeves RK, Jost S. A Natural Impact: NK Cells at the Intersection of Cancer and HIV Disease. Front. Immunol. 2019;10:1850.

3. Lanier LL, Le AM, Civin Cl, Loken MR, Phillips JH. The relationship of CD16 (Leu-11) and Leu-19 (NKH-1) antigen expression on human peripheral blood NK cells and cytotoxic T lymphocytes. J. Immunol. 1986;136(12):4480-4486.

4. Cooper MA, Fehniger TA, Caligiuri MA. The biology of human natural killer-cell subsets. Trends in Immunology. 2001;22(11):633-640.

5. Vivier E, Raulet DH, Moretta A, et al. Innate or adaptive immunity? The example of natural killer cells. Science. 2011;331(6013):44-49.

6. Chretien A-S, Fauriat C, Orlanducci F, et al. Natural Killer Defective Maturation Is Associated with Adverse Clinical Outcome in Patients with Acute Myeloid Leukemia. Front Immunol. 2017;8:573.

7. Chretien A-S, Devillier R, Fauriat C, et al. NKp46 expression on NK cells as a prognostic and predictive biomarker for response to allo-SCT in patients with AML. Oncoimmunology. 2017;6(12):e1307491.

8. Chretien A-S, Fauriat C, Orlanducci F, et al. NKp30 expression is a prognostic immune biomarker for stratification of patients with intermediate-risk acute myeloid leukemia. Oncotarget. 2017;8(30):4954849563.

9. Fauriat $C$, Just-Landi S, Mallet F, et al. Deficient expression of NCR in NK cells from acute myeloid leukemia: evolution during leukemia treatment and impact of leukemia cells in NCRdull phenotype induction. Blood. 2007;109(1):323-330.

10. Fauriat C, Marcenaro E, Sivori S, et al. Natural Killer Cell-triggering Receptors in Patients with Acute Leukaemia. Leukemia \& Lymphoma. 2003;44(10):1683-1689.

11. Chretien A-S, Granjeaud S, Gondois-Rey F, et al. Increased NK Cell Maturation in Patients with Acute Myeloid Leukemia. Front Immunol. 2015;6:564.

12. Khaznadar Z, Boissel N, Agaugué S, et al. Defective NK Cells in Acute Myeloid Leukemia Patients at Diagnosis Are Associated with Blast Transcriptional Signatures of Immune Evasion. J.I. 2015;195(6):25802590.

13. Dulphy N, Chrétien A-S, Khaznadar Z, et al. Underground Adaptation to a Hostile Environment: Acute Myeloid Leukemia vs. Natural Killer Cells. Front. Immunol. 2016;7:.

14. Chretien A-S, Le Roy A, Vey N, et al. Cancer-Induced Alterations of NK-Mediated Target Recognition: Current and Investigational Pharmacological Strategies Aiming at Restoring NK-Mediated Anti-Tumor Activity. Front Immunol. 2014;5:122.

15. Lucar O, Sadjo Diallo M, Bayard C, et al. B7-H6-mediated downregulation of NKp30 in natural killer cells contributes to HIV-2 immune escape: AIDS. 2019;33(1):23-32.

16. De Maria A, Fogli $M$, Costa $P$, et al. The impaired NK cell cytolytic function in viremic HIV-1 infection is associated with a reduced surface expression of natural cytotoxicity receptors (NKp46, NKp30 and NKp44). Eur. J. Immunol. 2003;33(9):2410-2418.

17. Zhou J, Amran FS, Kramski M, et al. An NK Cell Population Lacking FcRy Is Expanded in Chronically Infected HIV Patients. J.I. 2015;194(10):4688-4697.

18. Vendrame E, Seiler C, Ranganath T, et al. TIGIT is upregulated by HIV-1 infection and marks a highly functional adaptive and mature subset of natural killer cells: AIDS. 2020;34(6):801-813.

19. Mavilio D, Benjamin J, Daucher M, et al. Natural killer cells in HIV-1 infection: Dichotomous effects of viremia on inhibitory and activating receptors and their functional correlates. Proceedings of the National Academy of Sciences. 2003;100(25):15011-15016.

20. Mavilio D, Lombardo G, Benjamin J, et al. Characterization of CD56-/CD16+ natural killer (NK) cells: A highly dysfunctional NK subset expanded in HIV-infected viremic individuals. Proceedings of the National Academy of Sciences. 2005;102(8):2886-2891.

21. Björkström NK, Ljunggren H-G, Sandberg JK. CD56 negative NK cells: origin, function, and role in chronic viral disease. Trends in Immunology. 2010;31(11):401-406.

22. Taouk G, Hussein O, Zekak M, et al. CD56 expression in breast cancer induces sensitivity to natural killermediated cytotoxicity by enhancing the formation of cytotoxic immunological synapse. Sci Rep. 2019;9(1):8756.

23. Lanier LL, Chang C, Azuma M, et al. Molecular and functional analysis of human natural killer cellassociated neural cell adhesion molecule (N-CAM/CD56). J. Immunol. 1991;146(12):4421-4426. 
medRxiv preprint doi: https://doi.org/10.1101/2020.10.01.20204867; this version posted October 2, 2020. The copyright holder for this preprint (which was not certified by peer review) is the author/funder, who has granted medRxiv a license to display the preprint in

It is made available under a CC-BY-NC-ND 4.0 International license .

24. Chen L, Youssef Y, Robinson C, et al. CD56 Expression Marks Human Group 2 Innate Lymphoid Cell Divergence from a Shared NK Cell and Group 3 Innate Lymphoid Cell Developmental Pathway. Immunity. 2018;49(3):464-476.e4.

25. Mace EM, Gunesch JT, Dixon A, Orange JS. Human NK cell development requires CD56-mediated motility and formation of the developmental synapse. Nat Commun. 2016;7(1):12171.

26. Gunesch JT, Dixon AL, Ebrahim TA, et al. CD56 regulates human NK cell cytotoxicity through Pyk2. eLife. 2020;9:e57346.

27. Ziegler S, Weiss E, Schmitt A-L, et al. CD56 Is a Pathogen Recognition Receptor on Human Natural Killer Cells. Sci Rep. 2017;7(1):6138.

28. Nitta T, Yagita H, Sato K, Okumura K. Involvement of CD56 (NKH-1/Leu-19 antigen) as an adhesion molecule in natural killer-target cell interaction. The Journal of Experimental Medicine. 1989;170(5):17571761.

29. Hong HS, Eberhard JM, Keudel $P$, et al. Phenotypically and functionally distinct subsets contribute to the expansion of CD56-/CD16+ natural killer cells in HIV infection: AIDS. 2010;24(12):1823-1834.

30. Forconi CS, Cosgrove CP, Saikumar-Lakshmi P, et al. Poorly cytotoxic terminally differentiated CD56negCD16pos NK cells accumulate in Kenyan children with Burkitt lymphomas. Blood Advances. 2018;2(10):1101-1114.

31. Simoni Y, Fehlings M, Kløverpris HN, et al. Human Innate Lymphoid Cell Subsets Possess Tissue-Type Based Heterogeneity in Phenotype and Frequency. Immunity. 2017;46(1):148-161.

32. Setty $M$, Tadmor MD, Reich-Zeliger $S$, et al. Wishbone identifies bifurcating developmental trajectories from single-cell data. Nat Biotechnol. 2016;34(6):637-645.

33. Shimasaki N, Jain A, Campana D. NK cells for cancer immunotherapy. Nat Rev Drug Discov. 2020;19(3):200-218.

34. Tarazona R, Casado JG, Delarosa O, et al. Selective depletion of CD56(dim) NK cell subsets and maintenance of CD56(bright) NK cells in treatment-naive HIV-1-seropositive individuals. J. Clin. Immunol. 2002;22(3):176-183.

35. Alter $\mathrm{G}$, Teigen N, Davis BT, et al. Sequential deregulation of NK cell subset distribution and function starting in acute HIV-1 infection. Blood. 2005;106(10):3366-3369.

36. Müller-Durovic B, Grählert J, Devine OP, Akbar AN, Hess C. CD56-negative NK cells with impaired effector function expand in CMV and EBV co-infected healthy donors with age. aging. 2019;11(2):724-740.

37. Gonzalez VD, Falconer K, Michaëlsson J, et al. Expansion of CD56- NK cells in chronic HCV/HIV-1 coinfection: Reversion by antiviral treatment with pegylated IFN $\alpha$ and ribavirin. Clinical Immunology. 2008;128(1):46-56.

38. Björkström NK, Lindgren $T$, Stoltz $M$, et al. Rapid expansion and long-term persistence of elevated NK cell numbers in humans infected with hantavirus. The Journal of Experimental Medicine. 2011;208(1):13-21.

39. Nguyen S, Morel V, Le Garff-Tavernier M, et al. Persistence of CD16+/CD56-/2B4+ natural killer cells: A highly dysfunctional NK subset expanded in ocular myasthenia gravis. Journal of Neuroimmunology. 2006;179(1-2):117-125.

40. Reiners KS, Topolar D, Henke A, et al. Soluble ligands for NK cell receptors promote evasion of chronic lymphocytic leukemia cells from NK cell anti-tumor activity. Blood. 2013;121(18):3658-3665.

41. Lima M, Almeida J, Montero AG, et al. Clinicobiological, Immunophenotypic, and Molecular Characteristics of Monoclonal CD56-/+dim Chronic Natural Killer Cell Large Granular Lymphocytosis. The American Journal of Pathology. 2004;165(4):1117-1127.

42. Wanquet $A$, Prebet $T$, Berthon $C$, et al. Azacitidine treatment for patients with myelodysplastic syndrome and acute myeloid leukemia with chromosome 3q abnormalities: Azacitidine in 3q MDS/AML. Am. J. Hematol. 2015;90(10):859-863.

43. Devillier R, Gelsi-Boyer V, Murati A, et al. Prognostic significance of myelodysplasia-related changes according to the WHO classification among ELN-intermediate-risk AML patients: ELN-Intermediate Risk AML with Myelodysplasia-Related Changes. Am. J. Hematol. 2015;90(1):E22-E24.

44. Lausen B, Hothorn T, Bretz F, Schumacher M. Assessment of Optimal Selected Prognostic Factors. Biom. J. 2004;46(3):364-374.

45. van Unen V, Höllt T, Pezzotti N, et al. Visual analysis of mass cytometry data by hierarchical stochastic neighbour embedding reveals rare cell types. Nat Commun. 2017;8(1):1740.

46. Döhner H, Estey EH, Amadori S, et al. Diagnosis and management of acute myeloid leukemia in adults: recommendations from an international expert panel, on behalf of the European LeukemiaNet. Blood. 2010;115(3):453-474. 
medRxiv preprint doi: https://doi.org/10.1101/2020.10.01.20204867; this version posted October 2, 2020. The copyright holder for this preprint (which was not certified by peer review) is the author/funder, who has granted medRxiv a license to display the preprint in perpetuity.

It is made available under a CC-BY-NC-ND 4.0 International license

A

HV

HV\#75

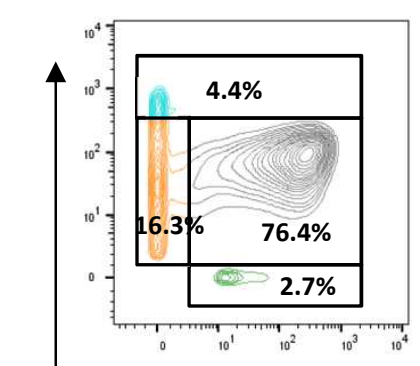

AML\#17

AML group 1

AML group 2

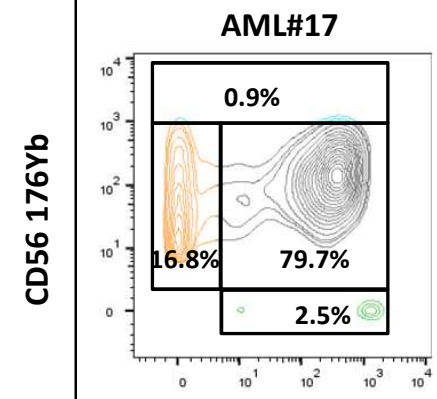

AML\#30

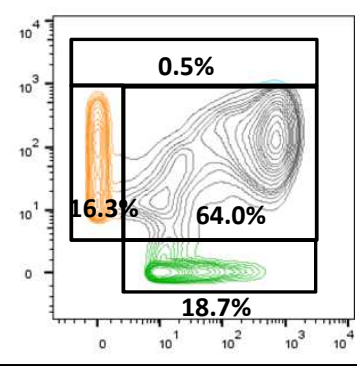

HV\#76

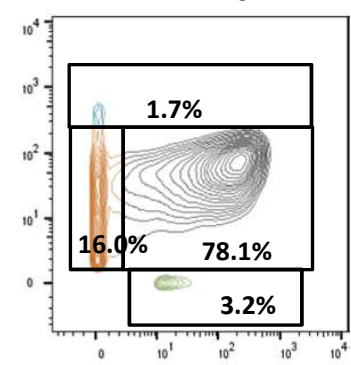

AML\#36

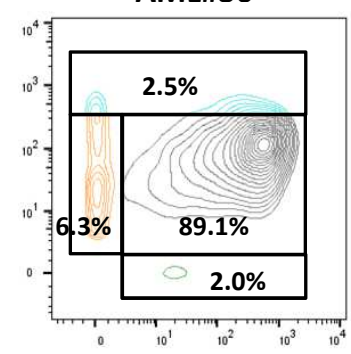

AML\#26

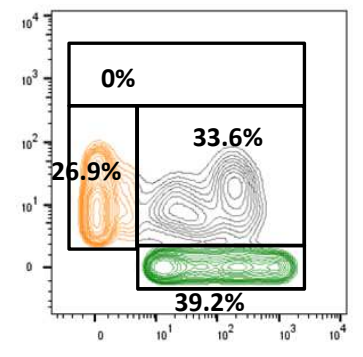

HV\#71

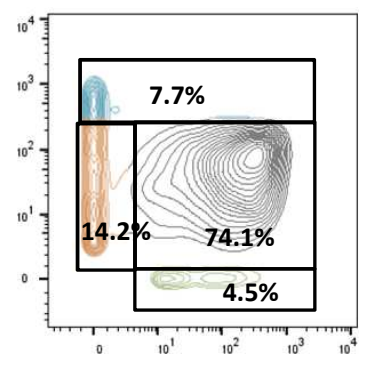

AML\#12

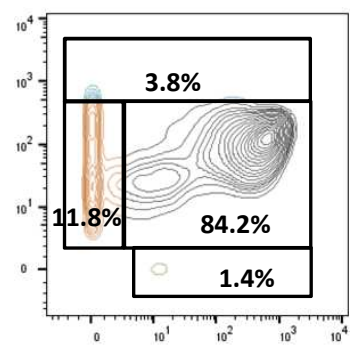

AML\#13

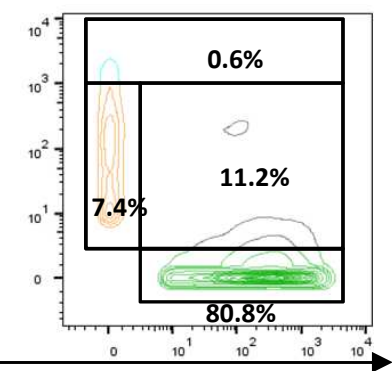

$10^{2}$

CD16 209Bi

B

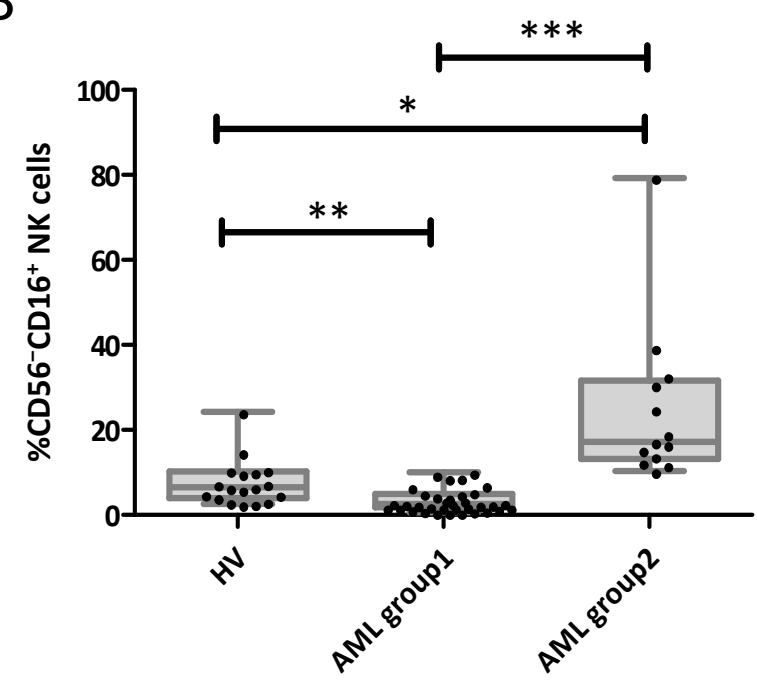

C

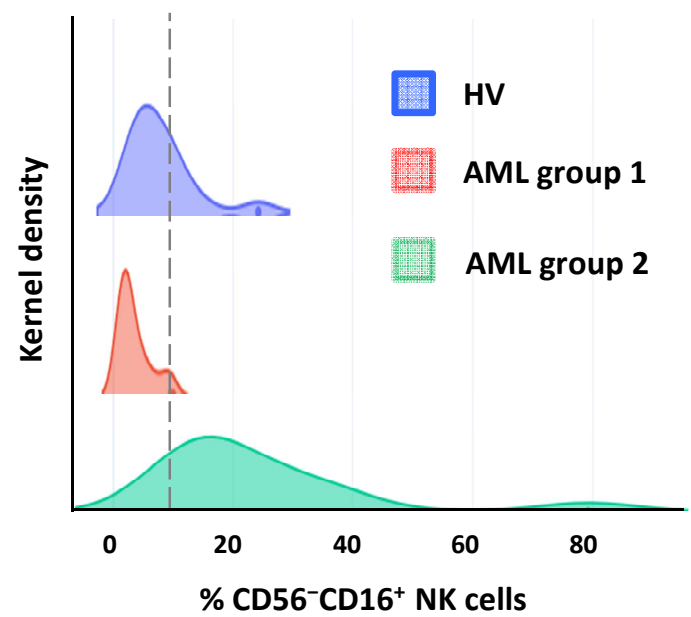

Figure 1. Accumulation of unconventional CD56-CD16 ${ }^{+}$NK cells in AML. PBMC from 48 newly-diagnosed AML patients and 18 HV were phenotyped by mass cytometry. (A) NK cell phenotype by CD56 and CD16 expression; representative examples of HV and AML patients without (group 1) or with (group 2) accumulation of CD56-CD16 ${ }^{+}$NK cells. (B) Frequency of CD56-CD16 ${ }^{+} \mathrm{NK}^{-}$ cells in HV and patients with AML. Results are presented as interquatile ranges, median, and whiskers from minimum to maximum. (C) Threshold visualization and value distribution illustrated by Kernel density estimation. HV, healthy volunteer. *: $\mathrm{P}<0.05 ; * *: \mathrm{P}<0.01 ; * * * \mathrm{P}<0.001$. 
medRxiv preprint doi: https://doi.org/10.1101/2020.10.01.20204867; this version posted October 2, 2020. The copyright holder for this preprint (which was not certified by peer review) is the author/funder, who has granted medRxiv a license to display the preprint in It is made available under a CC-BY-NC-ND 4.0 International license.

A

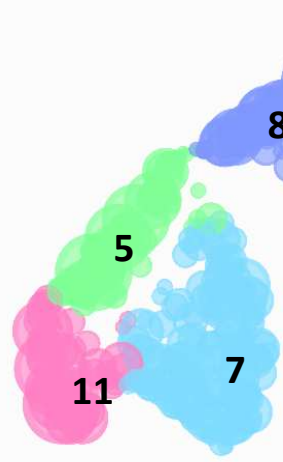

B

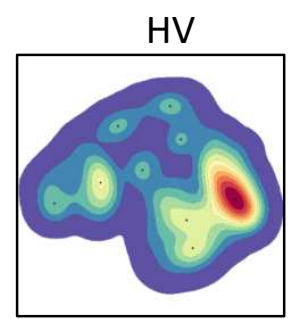

CD56

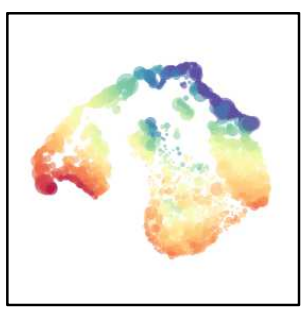

NKG2A

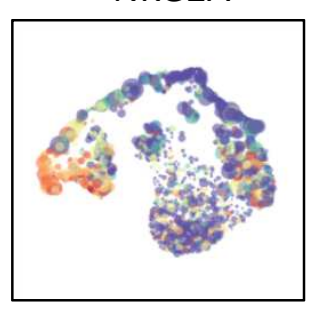

NKG2D

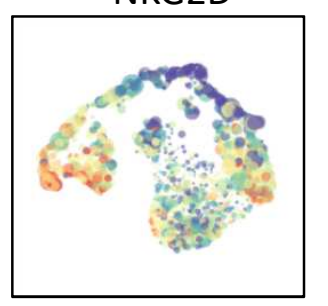

AML group 1

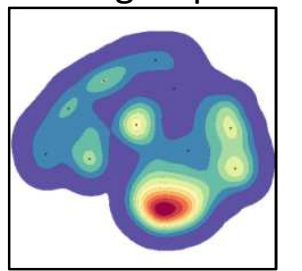

CD16
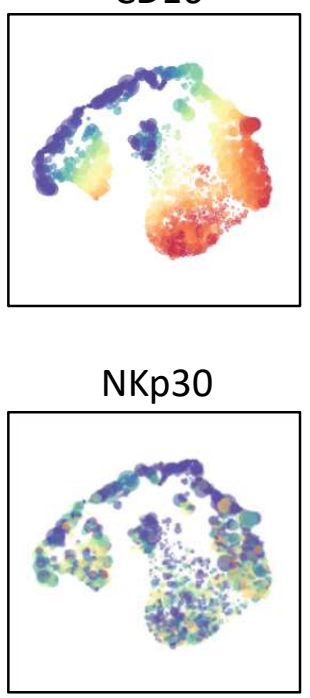

DNAM-1

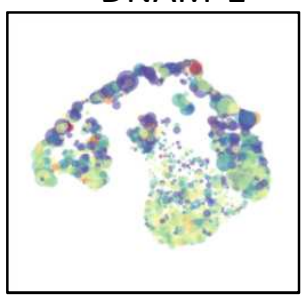

AML group 2

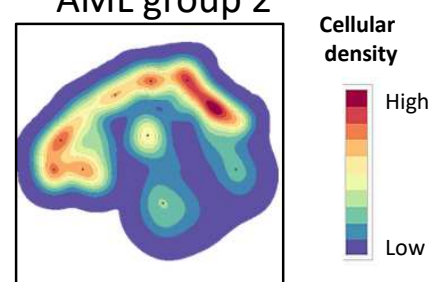

Marker

expression

High

Low

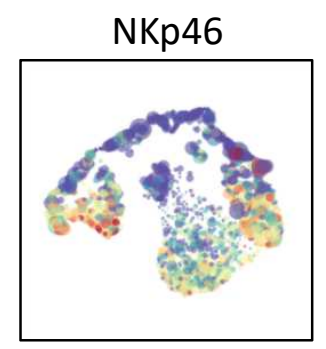

CD96

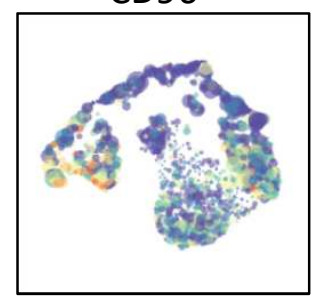

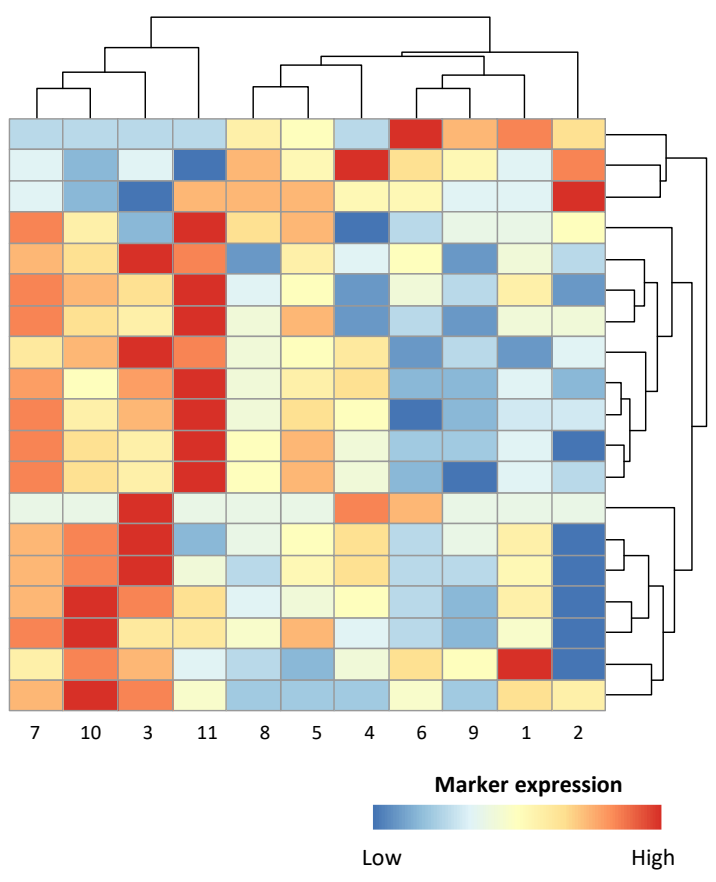

Figure 2. Loss of NK cell-triggering receptors in $\mathrm{CD}^{-} \mathrm{CD}^{-} 6^{+} \mathrm{NK}$ cells. (A) total NK cells from peripheral blood were manually pre-gated and exported in Cytosplore for h-SNE analysis. Consensus files were generated for each group of patients with fixed number of NK cells. Left panel: h-SNE enables identification of NK cell clusters based on CD56 and CD16 expression; right panel: the heatmap summarizes phenotypical characteristics of NK cell populations identified by h-SNE. (B) Expression of NK cell-triggering receptors projected on h-SNE maps. (C) Left panel: NK cell-triggering receptor expression profiles in clusters of CD56 bright, CD56 dimCD16-, CD56 ${ }^{\text {dim }}$ CD16 ${ }^{+}$, and $\mathrm{CD} 56^{-} \mathrm{CD} 16^{+} \mathrm{NK}$ cells were confirmed by manual gating to enable quantification of differences between clusters of NK cells. Results are presented as interquatile ranges, median, and whiskers from minimum to maximum. Data were analyzed using a Friedman test followed by a Dunn's test. Right panel: marker expression by NK cell subset; blue: CD56 bright NK cells; orange: CD56 ${ }^{\text {dim }}$ CD16 NK cells; grey: CD56 dim CD16 ${ }^{+}$NK cells; green: CD56-CD16 NK cells. *: $P<0.05$; **: $\mathrm{P}<0.01 ;{ }^{* * *}: \mathrm{P}<0.001 ;$ ns: non-significant. 
medRxiv preprint doi: https://doi.org/10.1101/2020.10.01.20204867; this version posted October 2, 2020. The copyright holder for this preprint (which was not certified by peer review) is the author/funder, who has granted medRxiv a license to display the preprint in It is made available under a CC-BY-NC-ND 4.0 International license.

C

HV

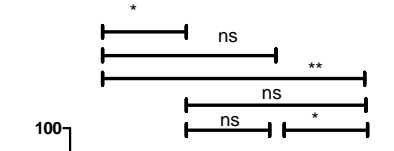

NKp30

NKp46

NKG2D

DNAM-1
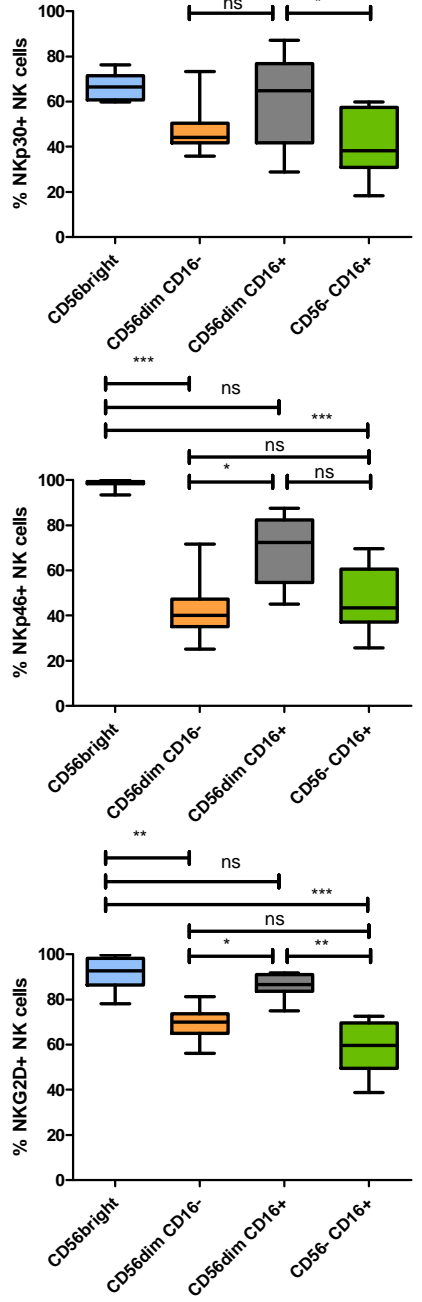

CD96
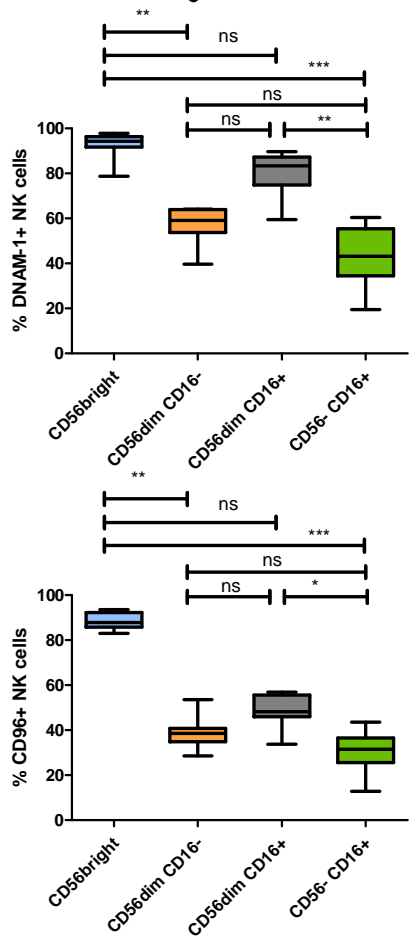

AML
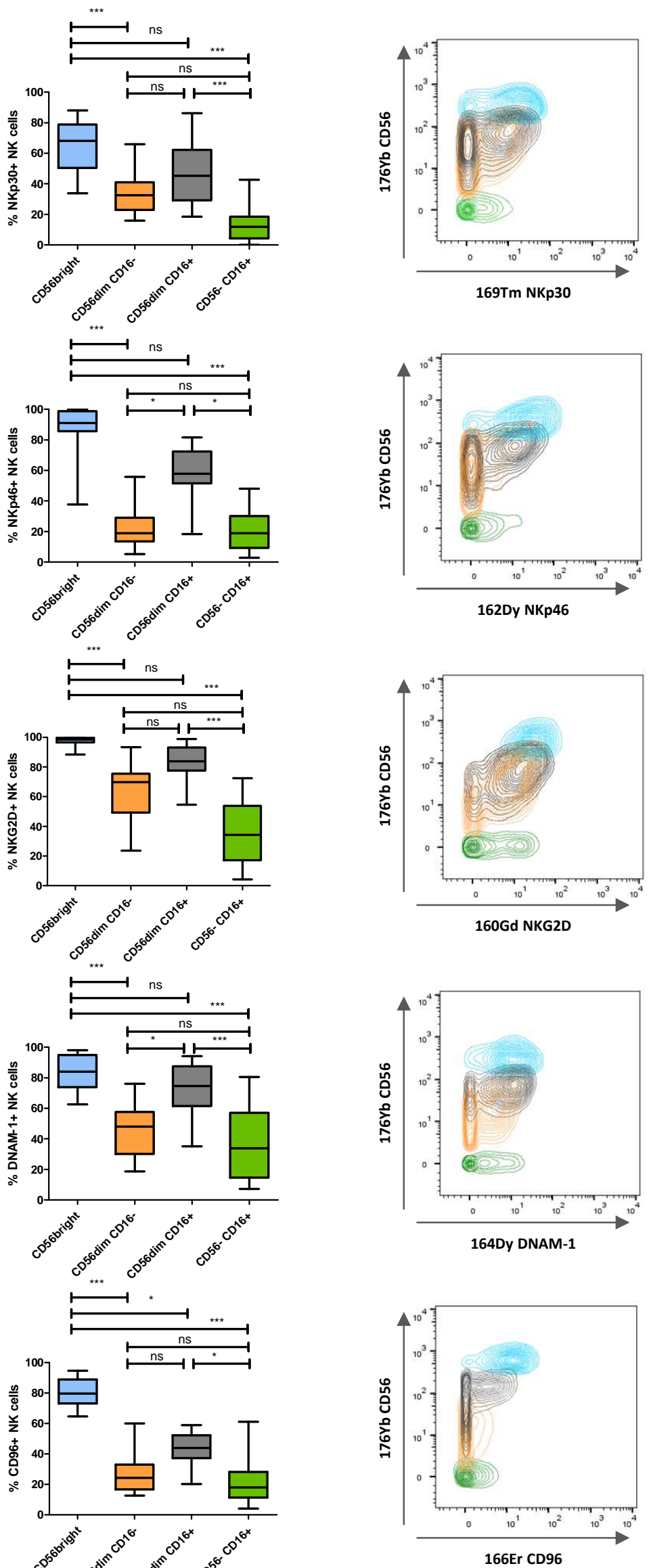

Figure 2 (continuation) 
medRxiv preprint doi: https://doi.org/10.1101/2020.10.01.20204867; this version posted October 2, 2020. The copyright holder for this preprint (which was not certified by peer review) is the author/funder, who has granted medRxiv a license to display the preprint in It is made available under a CC-BY-NC-ND 4.0 International license

HV

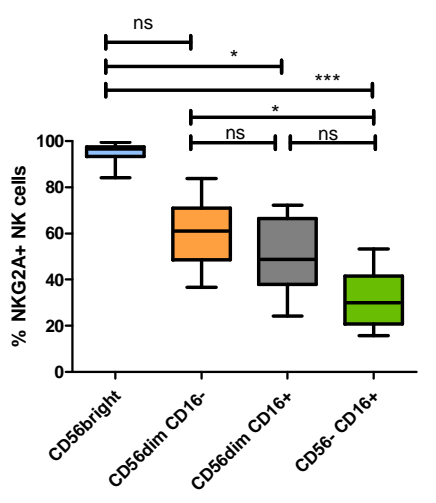

CD57

CD158a,h

$\mathrm{CD} 158 \mathrm{~b} 1, \mathrm{~b} 2, \mathrm{j}$
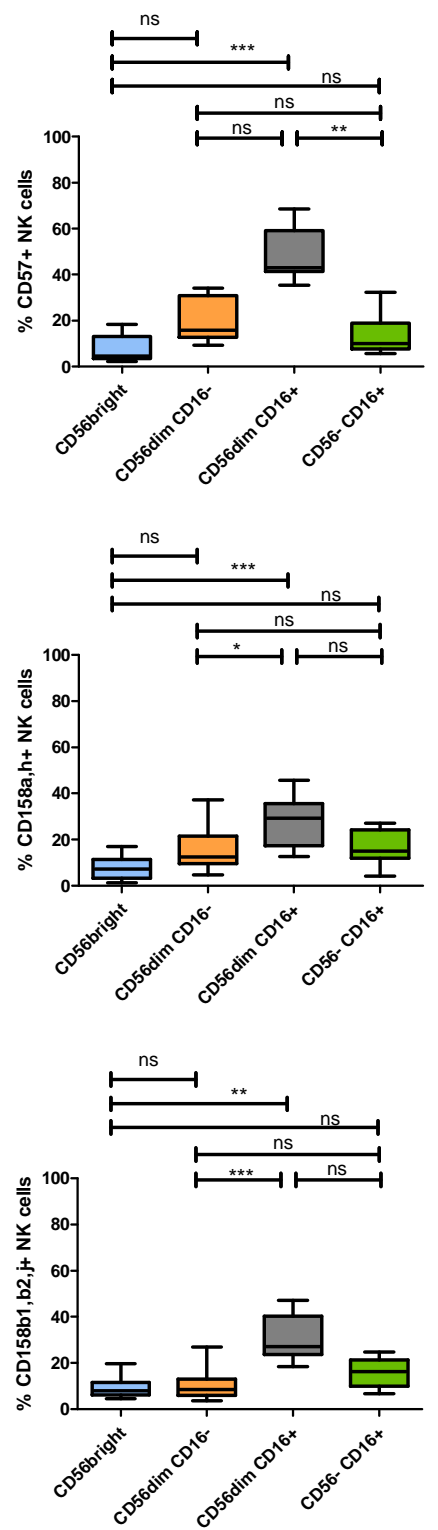

AML
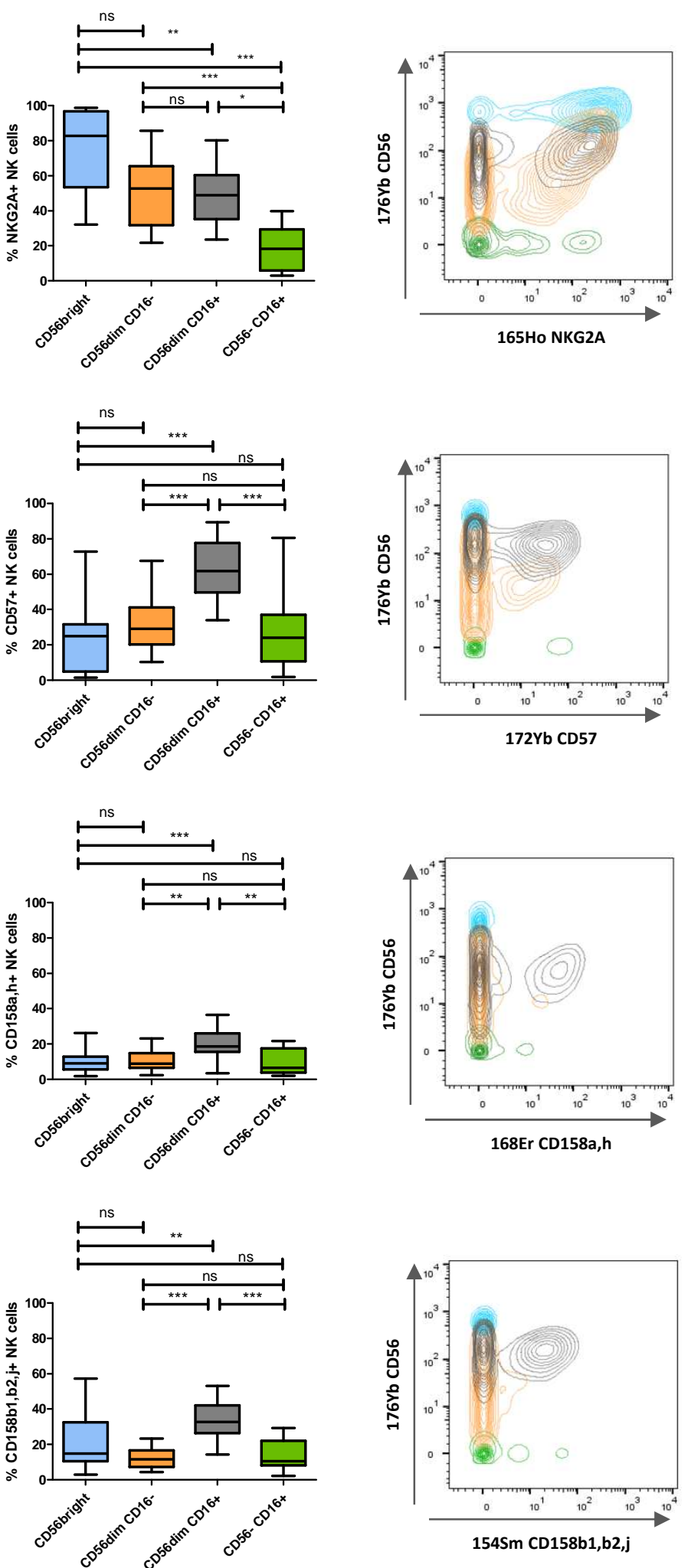

Figure 3. CD56-CD16 ${ }^{+}$NK cell clusters display intermediate maturation profiles. Left panel: expression of maturation markers in clusters of CD56 bright, CD56 dimCD16- CD56 dim CD16 ${ }^{+}$, and CD56-CD16 ${ }^{+} \mathrm{NK}$ cells was analyzed by manual gating. Results are presented as interquatile ranges, median, and whiskers from minimum to maximum. Differences between clusters were analyzed using a Friedman test followed by a Dunn's test. Right panel: marker expression by NK cell subset; blue: CD56 bright NK cells; orange: CD56 dim CD16NK cells; grey: CD56 ${ }^{\text {dim }}$ CD16 ${ }^{+}$NK cells; green: CD56-CD16 ${ }^{+}$NK cells. ${ }^{*}: \mathrm{P}<0.05 ;{ }^{* *}: \mathrm{P}<0.01 ;{ }^{* * *}$ : $\mathrm{P}<0.001$; ns: non-significant. 
medRxiv preprint doi: https://doi.org/10.1101/2020.10.01.20204867; this version posted October 2, 2020. The copyright holder for this preprint (which was not certified by peer review) is the author/funder, who has granted medRxiv a license to display the preprint in perpetuity.

It is made available under a CC-BY-NC-ND 4.0 International license .

$\mathrm{BCL}-2$
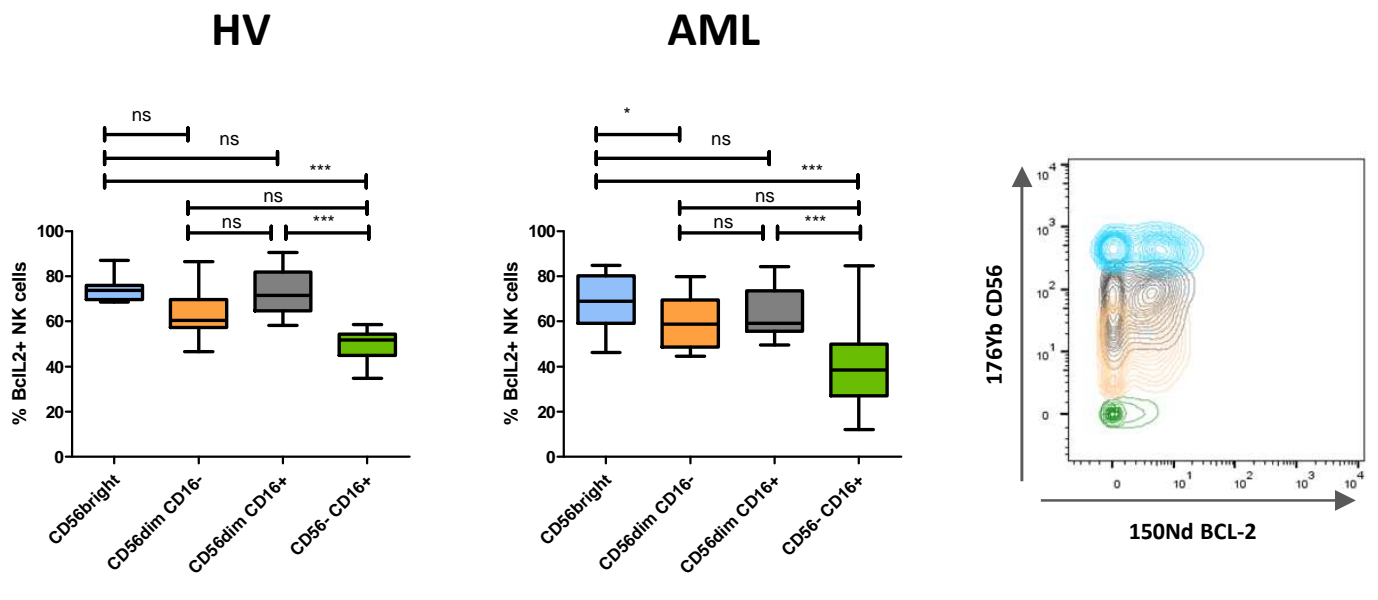

BCL-XL
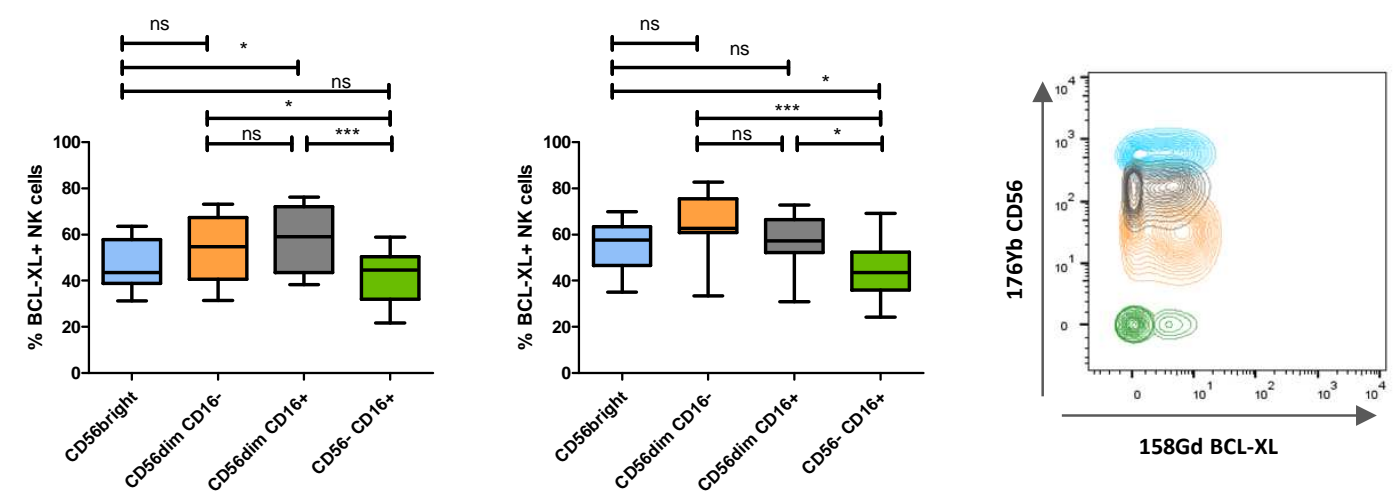

Figure 4. CD56-CD16 ${ }^{+}$NK cells display decreased expression of anti-apoptotic proteins. Left panel:

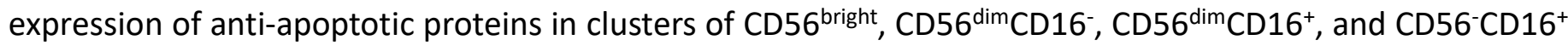
NK cells was analyzed by manual gating. Differences between clusters were assessed using a Friedman test followed by a Dunn's test. Results are presented as interquatile ranges, median, and whiskers from minimum to maximum. Right panel: marker expression by NK cell subset; blue: CD56 bright NK cells; orange: CD56 dim CD16- NK cells; grey: CD56 dim CD16+ NK cells; green: CD56-CD16+ NK cells. *: $\mathrm{P}<0.05{ }^{*}{ }^{* * *}$ : $\mathrm{P}<0.001$; ns: non-significant. 
medRxiv preprint doi: https://doi.org/10.1101/2020.10.01.20204867; this version posted October 2, 2020. The copyright holder for this preprint (which was not certified by peer review) is the author/funder, who has granted medRxiv a license to display the preprint in It is made available under a CC-BY-NC-ND 4.0 International license.

A

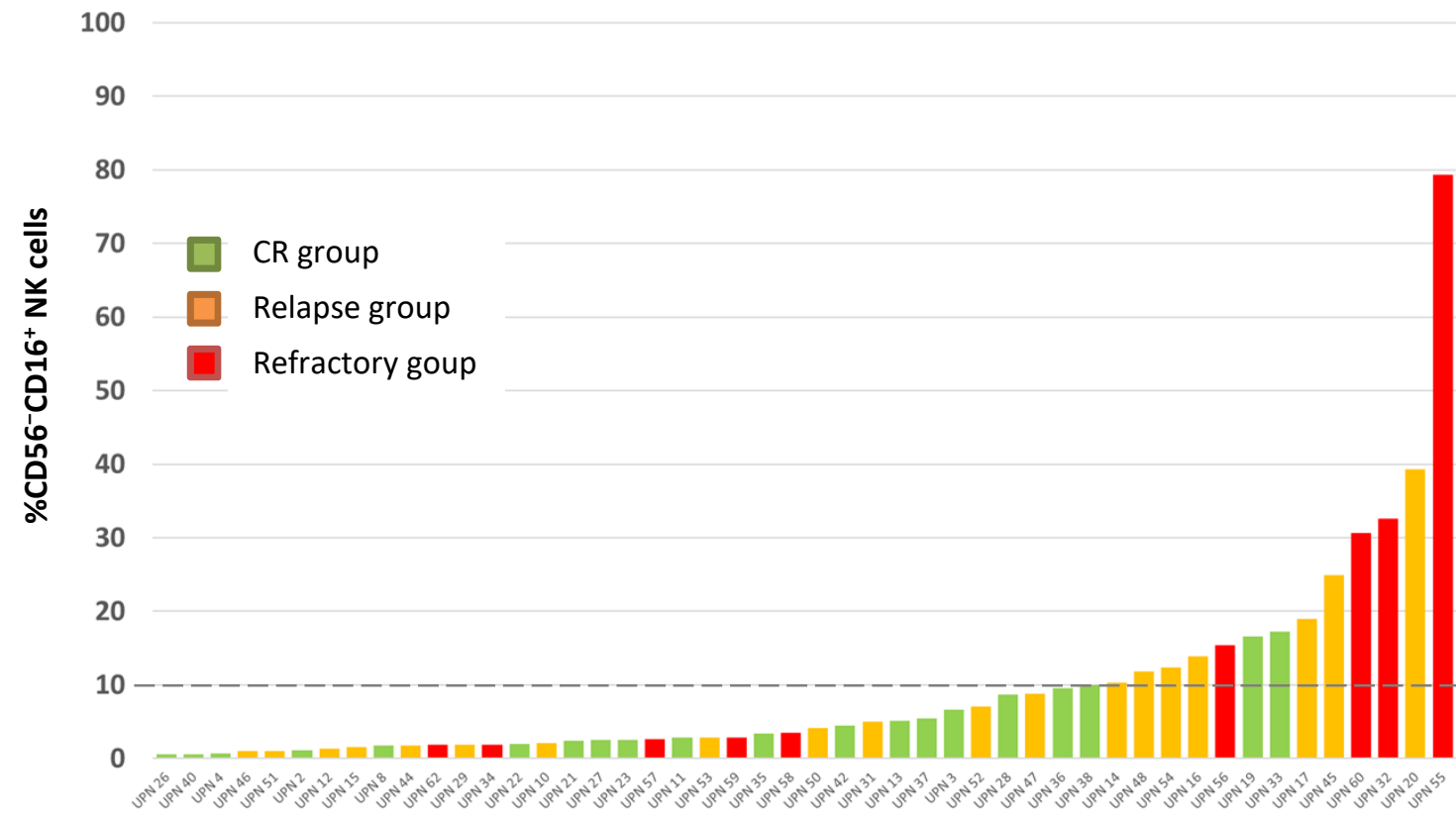

B

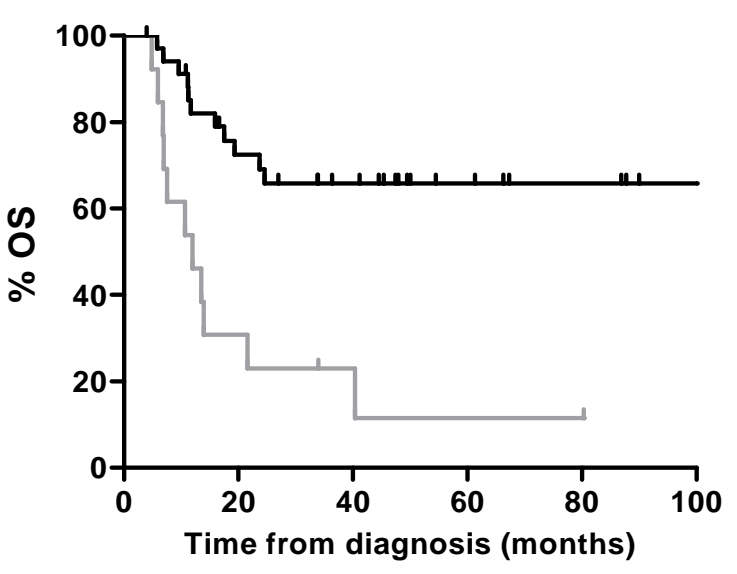

$P=.0002$

$\mathrm{HR}(\mathrm{Cl95})=0.13(0.05-0.38)$

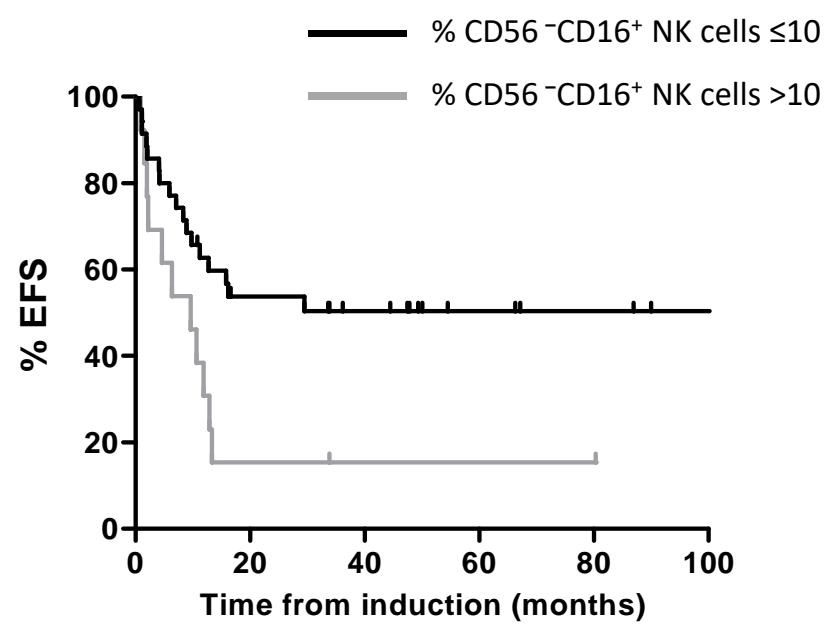

$\mathrm{P}=.018$

$\mathrm{HR}(\mathrm{Cl95})=0.33(0.13-0.83)$

Figure 5. High frequency of CD56-CD16 ${ }^{+}$NK cells at diagnosis is associated with adverse clinical outcome. (A) Frequency of CD56-CD16+ NK cells in AML patients at diagnosis according to clinical outcome after 24 months of follow-up. (B) Patients were stratified according to the frequency of CD56-CD $16^{+} \mathrm{NK}$ cells (group 1: $\mathrm{CD}^{-} 6^{-} \mathrm{CD} 16^{+} \mathrm{NK}$ cells $\leq 10 \%$; group 2: $\mathrm{CD}^{-} 6^{-} \mathrm{CD} 16^{+} \mathrm{NK}$ cells $\left.>10 \%\right)$. The impact of the accumulation of CD56-CD16 ${ }^{+}$NK cells on OS and EFS was assessed using a Log rank test. CI95, 95\% confidence interval; CR, complete remission; HR, hazard ratio; and UPN, unique patient number. 
medRxiv preprint doi: https://doi.org/10.1101/2020.10.01.20204867; this version posted October 2, 2020. The copyright holder for this preprint (which was not certified by peer review) is the author/funder, who has granted medRxiv a license to display the preprint in It is made available under a CC-BY-NC-ND 4.0 International license.

A

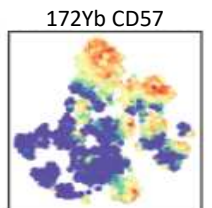

$165 \mathrm{Ho}$ NKG2A

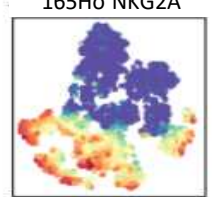

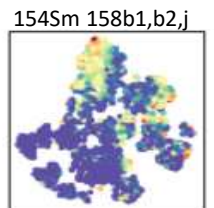

$176 \mathrm{Yb}$ CD56

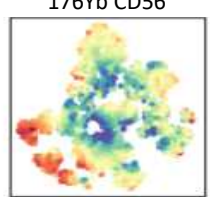

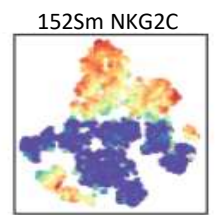

Wishbone trajectory Branch association

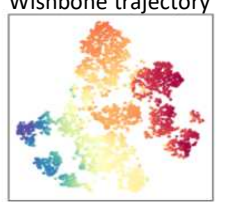

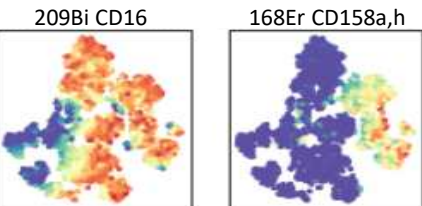

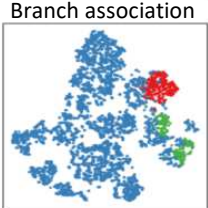

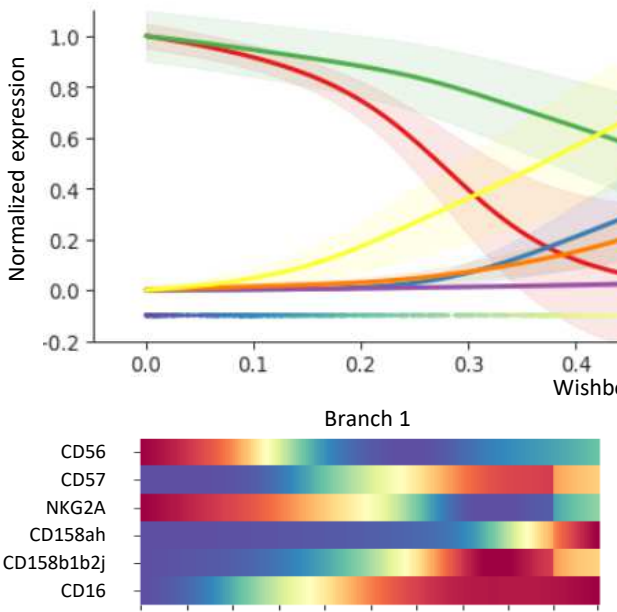

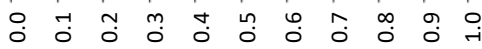
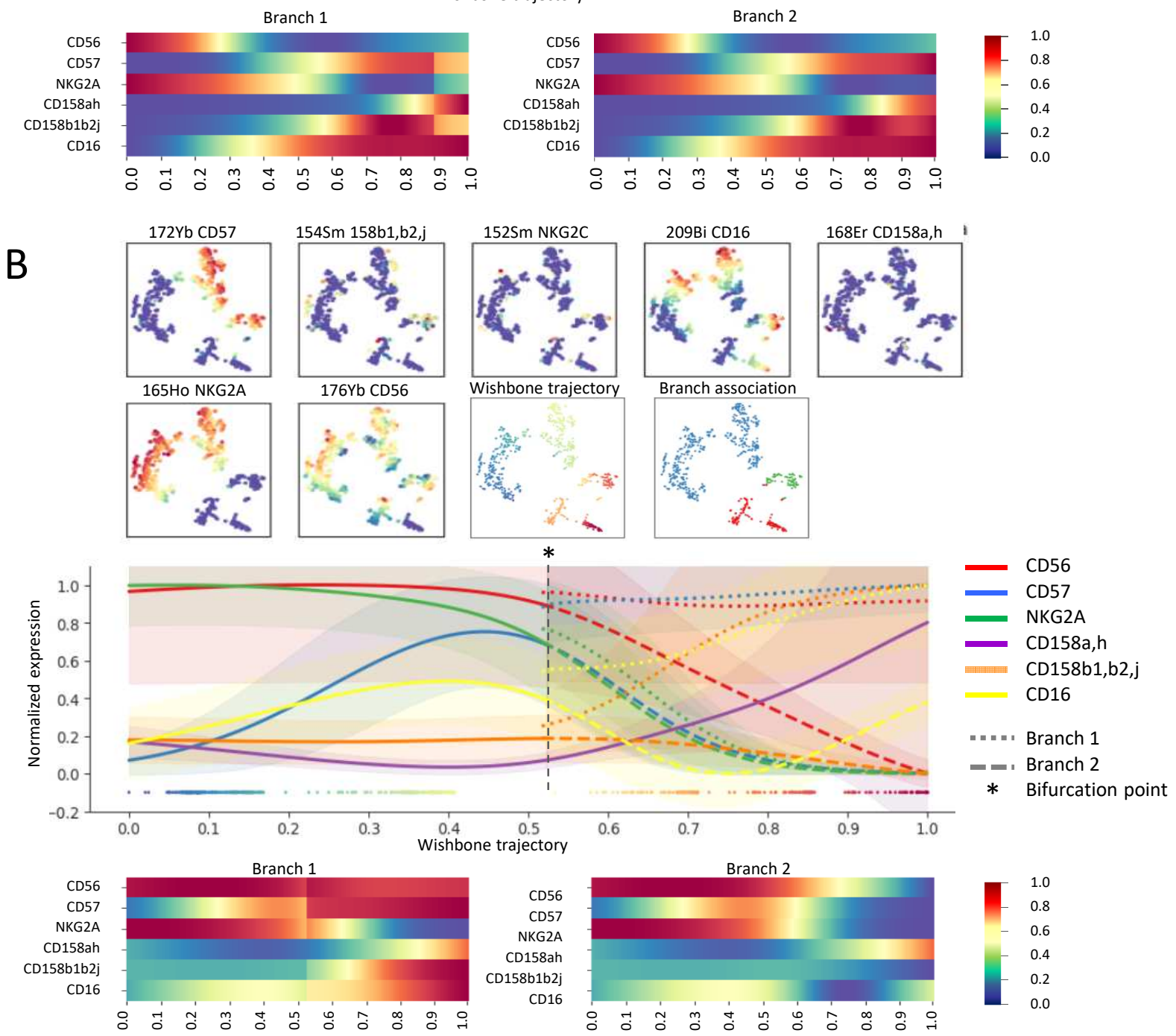

Figure 6. Differentiation trajectories are distinct for $\mathrm{CD} 56^{\operatorname{dim}} \mathrm{CD} 16^{+} \mathrm{NK}$ cells and $\mathrm{CD} 56 \mathrm{CD}^{-} 16^{+} \mathrm{NK}$ cells. NK cells were manually pre-gated and exported for differentiation trajectory inference using the Wishbone algorithm in HV (A) and AML patients at diagnosis (B). Wishbone enables identification of the branch point that gives rise to the population of $\mathrm{CD} 56^{-} \mathrm{CD} 16^{+} \mathrm{NK}$ cells. Ordering and branching of cells along bifurcating developmental trajectories was performed using t-distributed stochastic neighbor embedding (t-SNE) and diffusion maps. The resulting trajectory and branches are used to visualize the dynamics of maturation markers (CD56, CD57, NKG2A, and KIRs) and of CD16 during NK cell differentiation. 